\title{
TECHNOLOGICAL CHANGE AND \\ THE SKILL ACQUISITION OF \\ YOUNG WORKERS
}

\author{
Ann P. Bartel \\ Nachum Sicherman \\ Working Paper No. 5107 \\ NATIONAL BUREAU OF ECONOMIC RESEARCH \\ 1050 Massachusetts Avenue \\ Cambridge, MA 02138 \\ May 1995
}

This research was supported by a grant from the Office of Economic Research of the Bureau of Labor Statistics, U.S. Department of Labor, NLS Small Purchase Order Program. An earlier version of this paper was presented at the C.V. Starr Center Conference on Technologies and Skills, New York University, December 1994. We thank Steve Davis, Barbara Fraumeni, John Haltiwanger, Barry Hirsch, Saul Lach and Sam Kortum for providing us with various data sets used in this paper, and Eric Bartelsman for his help in matching the different datasets to the NLSY. Comments received from John Bishop, Boyan Jovanovic, Dan Black, Wilbert van der Klaauw and Joe Tracy are appreciated. This paper is part of NBER's research program in Labor Studies. Any opinions expressed are those of the authors and not those of the National Bureau of Economic Research.

(C) 1995 by Ann P. Bartel and Nachum Sicherman. All rights reserved. Short sections of text, not to exceed two paragraphs, may be quoted without explicit permission provided that full credit, including $\odot$ notice, is given to the source. 


\title{
TECHNOLOGICAL CHANGE AND \\ THE SKILL ACQUISITION OF \\ YOUNG WORKERS
}

\begin{abstract}
Using the National Longitudinal Survey of Youth (NLSY) and six proxies for industry rates of technological change, we study the impact of technological change on skill accumulation among young male workers in the manufacturing sector during the time period 1987 through 1992. Production workers in manufacturing industries with higher rates of technological change are more likely to receive formal company training, but not other types of training. An important finding is that, while more educated workers are more likely to receive formal company training, the training gap between the highly educated and the less educated narrows, on average, as the rate of technological change increases. The positive effect of technological change on hours of training is due largely to an increase in the incidence of training, not in the number of hours per training spell.
\end{abstract}

\author{
Ann P. Bartel \\ Graduate School of Business \\ Columbia University \\ 710 Uris Hall \\ New York, NY 10027 \\ and NBER
}

Nachum Sicherman

Graduate School of Business

Columbia University

717 Uris Hall

New York, NY 10027

and NBER 


\section{Introduction -}

The process of human capital accumulation during the early employment experiences of young workers has always been an area of active research and concern for policymakers; the human capital investments that occur during these early years shape an individual's career and impact the future productivity of the labor force. In an economy characterized by increasingly rapid technological change, the study of the process by which young workers accumulate human capital is especially relevant. Much of the current debate on the skills gap in the workforce revolves around the question of whether general or specific knowledge is more valuable in a rapidly changing environment. Indeed, increasing wage inequality between college and high school graduates might be interpreted to suggest that the status of less educated workers will deteriorate with the pace of technological change. This prediction ignores the impact of technological change on the post-schooling investments of different education groups; without such a study we can not explain how technological change will influence the wage gap between the more and less educated.

In this paper, we investigate the impact of technological change on young workers' investments in on-the-job training. Human capital theory does not provide a clear prediction on the sign of this relationship. Although higher rates of obsolescence will decrease training investments, technological _change may increase the productivity of human capital, reduce the cost of training, or increase the value of time in training relative to work. Hence, empirical analysis is needed to determine whether young workers receive more or less on-the-job training in response to technological change, and, in particular, how this relationship depends on the worker's education level. 
Economists have long been interested in the impact of technological change on the labor market. In the 1950s, the Bureau of Labor Statistics began its case studies of the impact of "automation" on employment. More recently, researchers' attention has focussed on the effect of technological change on the wage structure (Lillard and Tan, 1986; Mincer, 1989; Allen, 1992; Krueger, 1993; Berman, Bound and Griliches, 1994), the demand for educated workers (Bartel and Lichtenberg, 1987, 1991); inter-country differences in wage structures (Mincer and Higuchi, 1988) and retirement decisions of older workers (Bartel and Sicherman, 1993). But, only two studies, Lillard and Tan (1986) and Mincer (1989) have considered the impact of technological change on young workers and both of these papers have limitations which our paper overcomes.'

The major problem with earlier work on training and technological change is the limited information on training that was available to the researchers. We use the National Longitudinal Survey of Youth (NLSY) which is unique in terms of the comprehensiveness of the training information that is reported. Unlike other datasets, it includes detailed information on all formal training spells experienced by the individual, including the actual duration of the training. ${ }^{2}$ With this dataset, we can conduct a more comprehensive and reliable study of the training effects of technological change. The NLSY has the added advantage of covering the time period 1979 through 1992 enabling us to provide a more current analysis than previous studies.

The second way in which we improve upon previous research is by utilizing a variety of measures of technological change. Estimating the rate of technological change faced by the

\footnotetext{
'In order to study the training experiences of young workers, Lillard and Tan (1986) used the CPS and the NLS Samples of Young Men and Young Women, while Mincer (1989) analyzed the young workers in the PSID.

2Although Lynch (1991 and 1992) used the NLSY data to study the determinants of private sector training, her work did not analyze the role played by technological change. In addition, as we discuss in Section IIIA, we use a more accurate estimate of training duration.
} 
worker in his job is very difficult. Since the measurement of technological change outside the manufacturing sector is very problematic (Griliches, 1994), our analysis is restricted to workers in manufacturing. Even within this sector, however, no single proxy is likely to be perfect. We, therefore, link the NLSY with several alternative datasets that contain proxies for industries' rates of technological change. Specifically, our analysis uses the Jorgenson productivity growth series, the NBER productivity data, the Census of Manufactures series on investment in computers, the $R \& D /$ sales ratio in the industry, the industry's use of patents, and a measure of the rate of innovation obtained from a survey of $R \& D$ managers. Previous studies on training and technological change relied solely on the Jorgenson productivity growth series. Our analysis enables us to examine the robustness of alternative measures of technological change, thereby increasing confidence in the results.

Third, unlike the earlier research, we carefully dissect the relationship between technological change and training in order to answer the following questions: (1) How does technological change affect training investments for workers with different levels of education? (2) Does technological change increase both entry-level training and training of more experienced workers? (3) Does the pool of trainees increase in response to technological change, or is it mainly the previously trained workers who train more intensively? To our knowledge, this is the first paper to address these important questions.

Part II of the paper presents the theoretical framework that guides our empirical work. In Part III, we discuss the data sources for our study, explain the various measures of training and technological change, and present the basic equations that we estimate. Regression results are discussed in Part IV, and a summary is given in Part V. 


\section{Theoretical Framework}

\section{General}

In this section we examine the effects of technological change on job-training, utilizing the Ben-Porath (1967) (BP) model of optimal investment in human capital. In this model, individuals allocate their time between work and (job) training, with work generating income and training increasing the stock of human capital. The stock of human capital increases potential earnings, as well as the ability to generate additional human capital. The objective of the individual is to maximize the present value of his lifetime earnings, where retirement time is given, and utility from leisure is ignored. The Ben-Porath model is useful for providing basic insights into human capital investment decisions made by individuals. Alternatively, one could model the human capital investment decision from the perspective of the employer (for example, see Tan (1989)), but under standard assumptions (e.g. full information), the basic predictions will be unchanged.

Technological change is likely to affect several parameters in the Ben-Porath model that determine the level and patterns of investment in human capital. First, at higher rates of technological change, the rate of obsolescence of human capital is likely to be higher and this will affect the optimal path of investment. Second, technological change may act as a complement to the stock of human capital held by the individual (i.e., with the same stock the individual is more productive), thereby increasing the returns to human capital but also making training more costly because of the increase in opportunity cost ("foregone earnings"). Third, technological change may reduce the costs of direct inputs in the production of human capital (e.g., high tech learning devices) ${ }^{3}$. Finally, one of the simplifying assumptions in the BP model is that the cost of an hour diverted away from the

\footnotetext{
${ }^{3}$ The effects of technological change on the direct cost of learning could be far more complicated.
} 
market is equal to the value of this time in the production of human capital (the neutrality hypothesis). But, technological change may increase the value of time in the learning market, relative to its value in generating income, thereby requiring a relaxation of the neutrality assumption. Below we examine these effects. ${ }^{4}$

\section{The Ben-Porath Model}

In each time period, the individual possesses a stock of human capital, $\mathrm{K}_{t}$, which has a market rental rate of $\alpha_{0}$. Earning capacity at time $\mathrm{t}$ is given by $Y_{t}=\alpha_{0} K_{t}$. The parameter $\mathrm{s}_{\mathrm{t}}$ can be viewed as either the fraction of the available stock of human capital, or the proportion of time allocated to the production of human capital. Therefore, $\varsigma_{1} K_{t}$ is the proportion of human capital allocated to the production of human capital. The production function of human capital is given by:

$$
Q_{t}=\beta_{0}\left(s, K_{t}\right)^{\beta_{1}} D_{t}^{\beta_{2}}
$$

where $\beta_{1}, \beta_{2}>0$ and $\beta_{1}+\beta_{2}<1$. Investment costs in training $\left(I=\alpha_{0} s_{t} K_{t}+P_{d} D_{t}\right)$ have two components, the opportunity costs, and the direct costs.

The objective function of the individual at time $t$, is to maximize the present value of his disposable earnings, given by:

${ }^{4}$ By limiting our analysis to the BP framework, note that we do not consider two extensions that could be important in analyzing the effects of technological change: (1) adding leisure and consumption (see Ghez and Becker [1975], Blinder and Weiss [1976] and Heckman [1976]), and (2) the role of uncertainty (see Levhari and Weiss [1974] and Williams [1979]). 
$W_{t}=\int_{t}^{T} e^{-\mu}\left[\alpha_{0} K(\vec{\nu})-l(\nu)\right] d \nu$

subject to (1), $0 \leq S_{t} \leq 1$, and $\dot{K}_{t}=Q_{t}-\delta K_{t}$, and where $\delta$ is the rate of depreciation of human capital, $\mathrm{T}$ is the time of retirement, $\mathrm{r}$ the discount rate, and the expression in brackets is disposable earnings at time $t\left(E_{l}\right)$. Ben-Porath shows that the solution for $\mathrm{Q}_{t}$, the optimal production of human capital in each period is given by:

$$
Q_{1}=\beta_{0}\left(\frac{\beta_{0} \beta_{1}}{r+\delta}\right)^{\frac{\beta_{1}+\beta_{2}}{1-\beta_{1}-\beta_{2}}} \cdot\left(\frac{\beta_{2} \alpha_{0}}{\beta_{1} P_{d}}\right)^{\frac{\beta_{2}}{1-\beta_{1}-\beta_{2}}} \cdot\left[1-e^{-(r+\delta)(\gamma-t)}\right]^{\frac{\beta_{1}+\beta_{2}}{1-\beta_{1}-\beta_{2}}}
$$

Differentiating (3) with respect to time, gives the optimal change in the production of human capital over time:

$$
\dot{Q}_{t}=\frac{\beta_{1}+\beta_{2}}{1-\beta_{1}-\beta_{2}} \cdot \beta_{0}\left(\frac{\beta_{1} \beta_{1}}{r+\delta}\right)^{\frac{\beta_{1}+\beta_{2}}{1-\beta_{1}-\beta_{2}}} \cdot\left(\frac{\beta_{2} \alpha_{0}}{\beta_{1} P_{d}}\right)^{\frac{\beta_{2}}{1-\beta_{1}-\beta_{2}}} \cdot\left[1-e^{-(r+\delta)(T-1)]}\right]\left[\frac{\beta_{1}+\beta_{2}}{\left(1-\beta_{1}-\beta_{2}\right.}\right]^{-1} \cdot e^{(r+\delta)(T-t)}[-(r+\delta)]
$$

We now examine the various ways in which technological change is likely to affect the optimal path of investment in human capital.

\section{The Effects of Technological Change on Investment in Human Capital (Training)}

\section{(a) Increase in the rate of obsolescence}

According to the BP model, higher rates of depreciation of human capital reduce the marginal benefit of investment in human capital, thereby decreasing the optimal level of investment in human capital at any point in time (see equation 3 ).

In order to determine the effect of obsolescence on the time path (slope) of investment, we differentiate (4) with respect to $\delta$. The sign of this derivative depends on the parameters of the production function $\left(\beta_{1}+\beta_{2}\right)$, how close the individual is to retirement, 
(T-t), and the levels of $\delta$ and $\mathrm{r},(\mathrm{r}+\delta)$. If $\beta_{1}+\beta_{2}<1 / 2$, then $\frac{\partial \dot{Q}}{\partial \delta}=\frac{\partial^{2} Q_{1}}{\partial t \partial \delta}<0$, implying a sharper decline in investment over time. If $\beta_{1}+\beta_{2}>1 / 2$, it is possible for the investment profile to become flatter under certain values of the parameters mentioned above. The change of sign of the derivative, from negative to positive, is more likely to occur when the individual is closer to retirement, and when $\mathrm{r}$ and $\delta$ are relatively low. In the case of young workers who are far from retirement, an increase in the rate of obsolescence is, therefore, likely to result in a more sharply declining investment profile.

This approach assumes that the impact of technological change on the rate of obsolescence is identical for all types of human capital. However, certain types of human capital may be more immune to the introduction of new work processes. For example, the rate at which an individual's stock of general knowledge and problem-solving skills depreciates as a result of technological change is likely to be less than the rate for specific, vocational skills.

\section{(b) Increase in the Rental Price of Human Capital}

Within the BP framework, human capital is homogeneous, and its rental price is independent of the level of human capital. However, it is likely that the impact of technological change on the rental price of human capital will vary by type of human capital. For example, in an environment that changes more rapidly, general knowledge and a theoretical understanding of processes might become relatively more productive than ad-hoc knowledge, such as vocational education or knowledge based on experience.

An increase in the rental price of human capital has two opposite effects: It increases the cost of investment $\left(\frac{\partial l_{t}}{\partial \alpha_{0}}=s_{t} K_{t} \geq 0\right.$, and $\left.\frac{\partial M C_{t}}{\partial \alpha_{0}}>0\right)$, but also increases the demand price 
for human capital $\left(\frac{\partial P_{l}}{\partial \alpha_{0}}>0\right)$. However, differentiating (3) with respect to $\alpha_{0}\left(\frac{\partial Q_{l}}{\partial \alpha_{0}}>0\right)$

shows that an increase in the rental price of human capital unambiguously increases investment in each period, in spite of the increase in the cost of investment. To the extent that the increase in the rental price is stronger for general skills, this relationship reinforces the depreciation effect discussed above, making it more likely that investment in general skills will increase relative to investment in specific skills.

Differentiating (4) with respect to $\alpha_{11}$, we find that $\frac{\partial \dot{Q}_{t}}{\partial \alpha_{0}}=\frac{\partial^{2} Q_{t}}{\partial t \partial \alpha_{0}} \leq 0$; the investment

profile is steeper when the rental price is higher.

(c) Changes in the Value of Time in Investment Relative to Work.

As we explained above, the Ben-Porath neutrality hypothesis may not hold when technological change takes place. BP suggests that a more general production function can be used to account for such a possibility: $Q=\beta_{\left(5 r^{5}\right.}{ }^{\gamma_{1}} K^{\gamma_{2}} D^{\beta_{1}}=\beta_{\left(r^{5}\right.}{ }^{\gamma_{1}-\gamma_{2}}(s K)^{\gamma_{2}} D^{\beta_{2}}$

If, as a result of technological change, $\gamma_{2}$ becomes larger than, or increases more relative to $\gamma_{1}$, (i.e. the value of time in investment increases relative to its value in work), the result will be a flattening of the investment profile, or even a stretch of time over which investment rises rather than declines. If such a change occurs more so for certain types of workers, the increase in training at higher rates of technological change will be observed more among those workers. For example, if technological change simplifies the process of learning new skills, $\gamma_{2}$ could increase more for less educated workers, thereby leading to a relative (to the more educated) increase in their investment in human capital. 


\section{Conclusion}

We have shown that human capital theory does not provide a clear prediction with regard to the effect of technological change on the optimal level of on-the-job training. Higher rates of obsolescence will decrease the amount of investment. However, if technological change increases the productivity of human capital, reduces the cost of training, and/or increases the value of time in training relative to work, investment in training will increase. ${ }^{5}$ Our empirical analysis will show whether the negative effect of a higher depreciation rate is stronger or weaker than the combined positive effects.

We are also interested in analyzing how technological change affects the relationship between education and training. According to the Ben Porath model, more educated workers will train more, simply because human capital is an input in the production of new human capital. In the presence of technological change, however, we may see a weaker relationship between education and training. The discussion above in section $2 \mathrm{c}$ shows that this could happen if the process of learning new skills becomes simpler, thereby increasing the value of time in investment relatively more for the less educated workers. Another reason for a weaker relationship between education and training at higher rates of technological change is that technological change may increase the substitutivity of education and training in the production of human capital. ${ }^{6}$ The general skills of the more educated may enable them to adapt faster to the new technology, thereby dampening the otherwise positive impact of education on training.

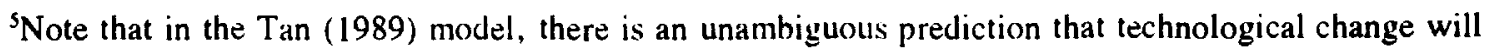
increase training because Tan assumes that technological change does not increase the rate of skill depreciation.

${ }^{6}$ Sicherman (1990) provides evidence that education and training are substitutes in the production of human capital.
} 


\section{Empirical Framework}

\section{A. Microdata}

We use the main file and the work history file of the 1987-1992 National Longitudinal Surveys of Labor Market Experience of Youth aged 14-21 in 1979 (NLSY) and restrict our analysis to males. The main file is the source of information on personal characteristics such as main activity during the survey week, education, age, race, marital status, health status, etc. An individual enters our sample when he first reports that his main activity during the survey week was "in the labor force." The work history file contains employment related spell data, such as wages, tenure, and separations, constructed from the main NLSY file. For each respondent, employment information is reported for a maximum of five jobs in each survey year. The work history file enables us to distinguish information for each job, especially the reasons for and timing of job transitions. One of these jobs is designated as a "CPS job" and it is the most recent/current job at the time of the interview. Typically it is also the main job. There are a host of important questions that are asked for the CPS job only, such as industry, occupation and firm size. Hence, our analysis is restricted to CPS jobs.

The NLSY is particularly well suited for a study of employee training because of the vast amount of information on the subject that is recorded. ${ }^{7}$ Data on a maximum of seven different training programs taken at any time since the last interview are included. Beginning with the 1988 survey, data on the following items are available for each of the seven training programs: starting and ending dates of the training program ${ }^{8}$, the number of weeks that the individual attended the program, what type of program it was (e.g. apprenticeships, company

\footnotetext{
'Like most other datasets, the NLSY provides information only on formal training. Ignoring informal training, a major portion of on-the-job training, is a drawback (see Sicherman, 1990).

${ }^{8}$ Not available for government programs.
} 
training, technical/vocational training off the job, (such as business college, nurses programs, vocational and technical institutes, barber or beauty school, a correspondence course)), government training; and how many hours he usually devoted per week to this program. In the NLSY, company training encompasses three types of training: (1) training run by the employer, (2) training run at work, not by employer, and (3) company training outside of work.

Prior to 1988 , detailed information on type of private sector training, as well as the weeks and hours per week spent in training, were only recorded if the training spell lasted at least four weeks. In other words, for the 1979 through 1986 time period, the researcher can measure incidence of private sector and government training, but it is impossible to determine if the private sector training was company-provided training, an apprenticeship program, or obtained in other ways such as a vocational/technical institute, business college, or correspondence course. In addition, even if the training spell lasted at least four weeks, the measure of training duration provided in the pre-1988 surveys is extremely unreliable because it is based on the starting and ending dates of the training program. ${ }^{9}$ In 1987 , no training questions were asked. However, training information for 1987 can be imputed from the 1988 data, thereby enabling us to add one more of data to our analysis; the regressions we report cover the time period 1987 through 1992.

Table 1 reports the incidence and duration of private sector training, by education and size of firm, for the manufacturing sector for the 1988 through 1992 time period. Incidence and duration are calculated on an annual basis. The data show that, on average, 17 percent of the individuals reported receiving private-sector training during the "twelve" month period

\footnotetext{
${ }^{9}$ For example, if an individual reported starting a training program in January of the survey year and finishing it in December of that year, training duration would be recorded as 52 weeks even if the individual had only received one day of training per month.
} 
between consecutive surveys ${ }^{10}$. Median duration of training was 40 hours, i.e. about one week, and the mean duration was 142 hours, or, approximately, three-and-one-half weeks. The probability of receiving private-sector training increases monotonically with education. The relationship between training duration and education is not monotonic; as we show below, this occurs because of the association between type of private sector training and education level.

The detailed data from the 1988 through 1992 surveys can be used to calculate the distribution of private sector training across three categories: (1) Company, or in-house, training; (2) Apprenticeships; and (3) Other training, such as training received in a business college, a nurses program, a vocational or technical institute, a barber or beauty school, or a correspondence course. For the entire sample, approximately $76 \%$ of private sector training is provided by the company. This percentage ranges from a low of $54 \%$ for the lowest education group to a high of $95 \%$ for the highest education group. Company training has a median duration of 40 hours for all education groups. This is considerably shorter than the median duration of apprenticeships, and somewhat shorter than the duration of other private sector training. Thus, although more educated individuals are more likely to receive private sector training, their training duration is shorter because their skills are acquired in company training programs rather than apprenticeships or other outside programs.

We distinguished large from small firms based on whether the number of employees in the individual's firm had at least 1000 employees. The data in Table 1 show that the incidence of company-provided training in large firms is $20 \%$ compared to only $7.7 \%$ in small firms, confirming the earlier findings of Barron, Black and Loewenstein (1987). The positive effect of firm size on the incidence of training holds for all education groups.

\footnotetext{
${ }^{10}$ Fifty-six weeks is the average length of time between survey dates.
} 


\section{B. Measures of Technological Change}

In order to estimate the model outlined in Part II, we require a measure of the rate of technological change faced by the individual in his place of work. If we could construct the ideal dataset, it would be to link the data in the NLSY with data on the firms for which the individuals work. Unfortunately, the employer name in the NLSY is confidential and researchers are not allowed access to it. We therefore link the NLSY with several alternative datasets that contain proxies for the industry's rate of technological change. ${ }^{\prime \prime}$ Below we describe each of these measures and analyze their strengths and weaknesses. Since no single proxy is a perfect measure, we feel it is important to use several alternative measures in our analysis. If similar results are obtained with different measures, we can have more confidence in the reliability of the findings.

The six measures of technological change that we use are (1) the total factor productivity growth series calculated by Jorgenson et.al. (1987) and updated through 1989, (2) the NBER total factor productivity growth series, (3) 1982 and 1987 Census of Manufactures' data on investment in computers, (4) the $R \& D /$ sales ratio in the industry as reported by the NSF, (5) the number of patents used in the industry and (6) a measure of the industry's rate of innovation obtained from the Yale survey of R\&D managers. Each of these measures has advantages and disadvantages as we describe below.

The Jorgenson total factor productivity series has been used extensively in previous research (for example, see Bartel and Sicherman (1993), Lillard and Tan (1986), Tan (1989), Mincer and Higuchi (1988) and Gill (1990)). There is substantial evidence from studies of

\footnotetext{
"An alternative approach would be to collect data from a small sample of firms that are undergoing technological change and analyze the impact on their employees. The disadvantage of this approach is that the findings may not hold for individuals who work in other firms. See Siegel (1994) for a study restricted to hightech firms on Long Island.

${ }^{12}$ Another approach is to create a composite index of technological change, following the approach used by Lichtenberg and Griliches (1989).
} 
the manufacturing sector that supports the claim that rates of productivity growth are highly correlated with technological change. Griliches and Lichtenberg (1984) showed that for the time period 1959-1976 there was a significant relationship between an industry's intensity of private R\&D expenditures and subsequent growth in productivity. Lichtenberg and Siegel (1991) also found that this relationship existed at the company level in the 1970s and 1980s. In using the Jorgenson productivity growth series, technological change is measured as the rate of change in output which is not accounted for by the growth in the quantity and quality of physical and human capital. One problem with this approach is that technological change may not be the only cause of productivity growth. Other factors, such as fluctuations in capacity utilization and non-constant returns to scale, are also likely to affect productivity growth. In order to control for these effects, the empirical analysis will include controls for the industry unemployment rate and the rates of entry and exit of firms in the industry. The Jorgenson series is currently available for the time period 1947 through 1989. The main advantage of the Jorgenson series is that changes in the quality of the labor input are carefully used to correctly measure net productivity growth. Also, the new Jorgenson series utilizes the BEA constant-quality price deflator; the earlier series underestimated productivity growth in high-tech industries (e.g. the computer industry) since quality improvements were not incorporated into the output price index. The major disadvantage of the Jorgenson series is that the data are reported for only 22 broad industry categories in the manufacturing sector, equivalent to two-digit SIC categories.

The NBER productivity database contains annual information on total factor productivity growth for 450 manufacturing industries for the time period 1958 through 1989. The advantage of the NBER database over the Jorgenson database is its narrow industry categories yielding data on approximately 100 three-digit industries in manufacturing. The 
disadvantage is that the productivity growth measure was not adjusted for changes in labor quality.

The third measure of technological change that we use is investment in computers. During the 1980s, there was an enormous growth in the amount of computer resources used in the workplace. Indeed, it has been argued (see Bound and Johnson, 1992) that the most concrete example of technological change in the 1980 s was the "computer revolution". ${ }^{13}$ Hence a more direct measure of technological change in the workplace may be the extent to which firms invest in information technology. We measure this by using the 1982 and 1987 Censuses of Manufactures that included a question on firms' investments in computers. We calculate the investment in computers as a share of total investments in each year and use both the 1982-87 growth in the share and the 1987 share as alternative indicators of technological change in the industry. ${ }^{14}$ The advantages of this measure are that (1) unlike data on R\&D expenditures, it measures use (not production) of an innovation and (2) it is available for several hundred four-digit industries in the manufacturing sector, which reduces to approximately 100 three-digit industries for the NLSY sample.

A fourth proxy for technological change is the ratio of company $R \& D$ funds to net sales reported by the National Science Foundation (1993) for industries in the manufacturing sector. The advantage of this variable is that it is a direct measure of innovative activity in the industry, but as indicated above, the innovative activity refers only to the industry in which the innovation originates, not the industry where the innovation is actually used.

The fifth measure of technological change is obtained from the dataset constructed by Kortum and Lach (1995) on the number of patents used in two-digit manufacturing

\footnotetext{
${ }^{13}$ Krueger (1993) used data from the Octoher 1984 and 1989 Current Population Surveys to show that workers who use computers on their job earn 10 to 15 percent higher wages.

${ }^{14}$ Berman, Bound and Griliches (1994) show that both the level and the change in the share of computer investments are good proxies for technological change in an industry.
} 
industries. Patent data are generally collected by technology field but Kortum and Lach (1995) propose a method for converting the number of patents per technology field into the number of patents used per industry. Their data are available for the time period 1957-1983. Since our analysis begins in 1987, we need a measure of patents used that is closest to that year. We could use the number of patents used by the industry during the 1980s, but the likelihood of an innovation being patented has differed historically across technology fields, and hence, across industries. In order to control for these systematic differences in the likelihood of patenting across industries, we construct the following variable for each twodigit manufacturing industry: the number of patents used by the industry during the years 1980 through 1983 , divided by the number of patents used by the industry during the 1970 s. Deflating the 1980s patents by the 1970s patents will control for differences in patenting probabilities across technology fields and, hence, industries. The main advantage of proxying technological change by "use of patents" is that, like the computer investment variable discussed earlier, it measures the direct use of innovations. The disadvantage is that the data are only reported for twenty manufacturing industries.

Finally, our sixth proxy is obtained from the 1983-84 Yale Survey on Industrial Research and Development. The survey was completed by high-level R\&D managers who were knowledgeable about the relevant technology and market conditions in their lines of business. Six hundred and fifty managers from 130 lines of business ( 4 or 3 digit classification) responded to the survey. ${ }^{15}$ We use the responses to the following question on the survey: "Since 1970, at what rate have new or improved production processes been introduced in this line of business?" While this question appears to be the ideal description

\footnotetext{
${ }^{15}$ The sample does not include firms that did not have publicly traded securities. As a result, there is an underrepresentation of small firms, and nearly all start-up ventures, an important source of innovation, are excluded.
} 
of technological change, the manner in which the responses were coded may limit the variable's usefulness. The managers were asked to respond to the question by using a scale that ranged from 1 to 7 without any guidelines as to the meaning of the numbers on the scale or any reference points regarding high or low rates of innovation. Results using this variable should be treated with caution given the highly subjective nature of the responses.

Table 2 presents industry means of the various proxies for technological change. Each listing is presented in rank order so that we can observe whether the six proxies produce similar patterns regarding high and low technological change industries in the manufacturing sector. We find that some industries appear at the top or near the top of each measure's list. Using the Jorgenson data, non-electrical machinery has the highest rate of technological change and electrical machinery is tied for second place with petroleum refining. The computer investment data provides information for more detailed industries; the three industries with the highest computer share of investment, electronic computing equipment, radio, T.V., and communication equipment, and office and accounting machines, are members of the broader non-electrical machinery and electrical machinery categories. For the NBER productivity measure, electronic computing equipment has a significantly larger value than the other manufacturing industries. The $R \& D /$ sales ratio data show office, computing and accounting machines as the top-ranking industry. For the patent variable, office and computing machines and communication and electronics rank at the top. In the case of the Yale measure, more confidence should be placed in the industry measures that were obtained from larger numbers of responses per industry. ${ }^{16}$ Looking at those industries where at least six observations were obtained, we find that, as with the other measures,

\footnotetext{
${ }^{16}$ The fact that only one observation was obtained for the tobacco industry probably explains why this industry ranks at the top for this measure of technological change, but at or near the bottom for the other measures.
} 
electronic computing equipment and radio, T.V. and communication equipment rank at the top for this measure of technological change.

The fact that the two or three industries that we generally think of as "high-tech" industries rank at the top for all six measures of technological change is evidence that the six variables are good indicators of technological change. One might be attempted to generalize from these cases and conclude that, since all six proxies appear to be measuring the same thing, perhaps only one proxy should be used for the analysis. A closer look at the six listings indicates, however, that they each contribute unique information about the differences in the rates of technological change in the manufacturing sector. For example, according to the computer investment measure, leather products has a relatively high rate of technological change, but this is not captured by the other proxies. By comparison, petroleum refining ranks high for the Jorgenson and NBER productivity measures and the patent variable, but not for the other three proxies. Additional comparisons of the six listings also demonstrate that, in many cases, the rankings are dissimilar. This indicates the value of using all six proxies in our analysis. Technological change is a difficult concept to quantify in a unique way; each proxy is likely to capture a different dimension of technological change. If all proxies produce similar results about the impact of technological change on training, confidence in our conclusions will be significantly enhanced.

\section{Matching the Microdata and Industry Measures}

Since our NLSY panel covers a short time span (1987-1992) and there is a high degree of randomness in annual changes in the technological change measures that are available on an annual basis, it is impossible to conduct a true time-series analysis. Our analysis therefore relies on cross-section variations in technological change. All of the measures that we use have a common trait, i.e. they are proxies for the industry rate of technological change. We recognize that an industry measure of technological change may 
not have the same impact for all of the occupations in that industry. For example, an innovation in the industry's production processes may have little or no impact on clerical employees. By matching an industry measure of technological change to all of the individuals in that industry we are less likely to find a strong effect of technological change. Hence, our empirical results are likely to be underestimates of the true relationship. We deal with this issue by conducting separate analyses for production and non-production workers, since in most cases production workers are more likely to be affected by technological change in the manufacturing sector. Another issue is that the standard errors of our estimated coefficients may be biased downwards because industry-level shocks may be correlated across individuals within a given industry.

In order to match the different measures of technological change to the industrial classification used in the NLSY (the Census of Population classification), we use industry employment levels as weights whenever aggregation is required. When we utilize the Jorgenson and NBER productivity growth measures, we characterize industry differences in the rate of technological change by using the mean rate of productivity growth over the most recent ten-year time period, i.e. 1977-1987. In the case of investment in computers, we use data from 1982 and 1987 as described earlier. The $R \& D /$ sales ratio for each industry is calculated as a three-year moving average for the three year period prior to the year of analysis, e.g. averaging data for 1984-1986 for the 1987 NLSY, etc. For the patent data, we calculate the number of patents used during the time period $1980-83$ divided by the number used during the 1970s. Finally, the innovation measure from the Yale survey refers to the time period 1970-1983. Hence, with the exception of the R\&D variable, we use a fixed time period measure of technological change which may act like a fixed effect for each industry, capturing other fixed attributes of the industry. We deal with this problem by including several industry characteristics in the regressions which we believe may influence the 
relationship between training and our measures of technological change. They are: the annual industry unemployment rate obtained from Employment and Earnings, annual measures of percent unionized in the industry compiled from the CPS by Hirsch and MacPherson (1993), and the annual rates of job creation and job destruction for both start-up and continuing establishments in the industry constructed by Davis and Haltiwanger (1992).

\section{Econometric Models}

\section{The Likelihood of Company Training}

Our econometric analysis is restricted to company training because, as was shown in Table 1, three-quarters of private-sector training is provided by the firm. We do provide some evidence of the impact of technological change on other forms of private-sector training and contrast these effects with those for company training.

In order to estimate the effect of technological change on the likelihood of company training, we adopt a simple Logit framework. In each period, between two surveys, an individual will face one of the following two alternatives described by $j$ : Engage in company training $(j=1)$, or not $(j=0)$.

The choice $\mathrm{j}$ occurs when the latent variable $Y_{i j}^{*}>0$, where

$$
Y_{i j}^{*}=X_{i j} \alpha_{j}+\delta_{j} T_{i i}+\epsilon_{i j}
$$

where $\mathrm{i}$ is the individual index, $\mathrm{t}$ is time, $\mathrm{j}$ is the alternative, $X_{i j}$ is a vector of individual, job, and industry characteristics that may vary over time. The vector $\mathrm{X}$ includes the following variables: marital status, race, years of education, residence in an SMSA, years of experience and its square, tenure and its square, union membership, whether or not the individual is employed by a large firm, the industry unemployment rate, union coverage in the industry, and job creation and destruction in the industry. $T_{i t}$ is the rate of technological 
change in the industry in which the individual is working at time $\mathrm{t}$. In order to test whether the effect of technological change varies by education group, in some of our specifications we interact the proxies for technological change with education group.

Assuming that $\epsilon$ is logistically distributed ${ }^{17}$ gives rise to a logit model in which the underlying probabilities are

$$
P_{j}=\frac{\exp \left(Z \beta_{j}\right)}{\sum_{k=0}^{l} \exp \left(Z \beta_{k}\right)}, j=0,1
$$

In order to identify the parameters, the normalization $\beta_{0}=0$ is imposed and the estimated parameters are obtained by maximum likelihood.

\section{Hours of Company Training}

In order to estimate the effects of technological change on the amount of time spent in company training, we adopt a standard Tobit model. As McDonald and Moffitt (1980) show, the Tobit coefficients measure the effects of the covariates on the dependent variable (hours of training), resulting from both the change in the likelihood of being above the limit (getting training), and from the change in the value of the dependent variable (hours of training) if it is already above the limit. In Appendix D, we outline the Tobit model and describe the decomposition procedure suggested by McDonald and Moffitt. The independent variable used in the Tobit models are the same as those used in the Logit regressions.

\section{Results}

\section{A. Incidence of Company Training}

A summary of the estimates from our logit models on the incidence of company training in the manufacturing sector is shown in Table 3. Complete regression results for

\footnotetext{
${ }^{17}$ This is not a strong assumption. In practice, our results were very similar using probit, and even OLS. For more details, see Amemiya, 1981.
} 
one model are given in Appendix B where we see the typical patterns regarding the effect of education, firm size, and other characteristics on the incidence of training. ${ }^{18}$ In this section, we detail the relationship between technological change and the incidence of training; in all of our specifications, we control for four additional industry characteristics: the unemployment rate, percent of workers who are union members or covered by a union contract, the annual rate of job creation, and the annual rate of job destruction.

Table 3 shows the effects of each of the six technological indicators on the incidence of training for all workers in the manufacturing sector (column 1) and for production and non-production workers separately (columns 2 and 3, respectively). We present the logit coefficient and the estimated probability that the coefficient is not different from zero (shown in parentheses beneath the coefficient). To the right of each coefficient, we show the derivative $(\mathrm{dP} / \mathrm{dX})$ multiplied by the standard deviation of the measure of technological change. This estimate enables us to compare the magnitudes of the effects of the various technological change measures. The results in column (1) show that all six proxies for technological change have a positive and significant effect on the incidence of training in the manufacturing sector, indicating that the negative effect of technological change due to the increase in the rate of depreciation is outweighed by the positive effects relating to increased productivity of human capital, reductions in the cost of training, and/or increases in the value of time in training relative to work. The largest impacts are observed for the Jorgenson TFP measure, the $R \& D$ /sales ratio and use of patents. Comparing the results in column (2) with those in column (3) shows that, with the exception of the Yale Survey measure, the impact of technological change on the incidence of training is larger for production workers than non-

\footnotetext{
${ }^{18}$ In Appendix B, the full specification using the R\&D/sales ratio is presented. The coefficients on the nontechnological change variables are very similar to those shown in Appendix B when the other proxies for technological change are used.
} 
production workers, as anticipated. ${ }^{14}$ In fact, the estimated coefficients for non-production workers are not statistically significant.

Although three-quarters of private sector training is provided by the firm, young workers do receive some training outside the firm. In Table 4 , we consider whether technological change also has a positive impact on non-company training. In columns (1) through (3), the dependent variable is the likelihood of any type of private sector training (company or non-company), and in columns (4) through (6), we show results for the likelihood of non-company training. Since the vast majority of private-sector training is company-provided, the results in columns (1) through (3) are quite similar to those reported in Table 3. The analysis of non-company training alone shows that, with the exception of the Jorgenson TFP measure, technological change does not have a significant effect. ${ }^{20}$ Hence, the remainder of our analysis is confined to company training.

As we discussed in the Introduction, it is important from a policy perspective to estimate the effect of technological change on the post-schooling human capital investments of different education groups. Our theoretical discussion provided two reasons why the impact of technological change on the incidence of training may vary by education. One reason is that more educated individuals may require less training in response to technological change if their general skills enable them to learn the new technology and adapt to the changed environment, i.e. training and education are substitutes in production. This narrowing of the training gap between the highly educated and the less educated can also occur if technological change simplifies the process of learning new skills, thereby increasing

\footnotetext{
${ }^{19}$ As shown in Table 2, the number of responses to the Yale Survey varied by industry. It could be argued that the accuracy of the Yale measure increases with the number of responses. Hence, we also estimated a variant of the Yale regression in Table 3 that allowed for separate effects of the Yale innovation measure for cases where the number of responses was less than or equal to two and cases where the number of responses was greater than two. The estimated coefficients did not differ for these two groups.
}

${ }^{x}$ Furthermore, the significance level of the Jorgenson variable is considerably smaller in Table 4. 
the value of time in investment relative to its value in work from the less educated. We test these hypotheses in Table 5 where the regressions include an interaction effect between education and the proxy for technological change.

The results in Table 5 show that for all workers, production and non-production workers alike, the more educated are more likely to receive company training. ${ }^{21}$ The interaction effects show, however, that technological change attenuates the impact of education on training. At higher rates of technological change, the training gap between the highly educated and the less educated is narrower. The separate results for the production and non-production workers generally support this conclusion. Whenever the technological change indicator has a positive and significant effect on the incidence of training, the education-technological change interaction effect is negative and usually significant.

In order to more fully understand the relationship between technological change and the incidence of training for different education groups, we estimated the regressions in Table 4 using a set of dummies for education groups $(1-8,9-11,12,13-15,16$, and $17+$ years of schooling) in place of the continuous measure, and interacted the dummy variable with the technological change indicator. The coefficients from these regressions are shown in Table 6. We used these coefficients to create plots (see Figures 1-4) that depict the impact of technological change on the incidence of training for a worker of given characteristics in each education group. ${ }^{22}$ Figures 1 and 2 are based on investment in computers, for production and non production workers respectively, and figures 3 and 4

\footnotetext{
${ }^{21}$ See Appendix B for separate coefficients on education groups. The results show a monotonic relationship between years of education and training.

${ }^{22}$ For these plots, we assumed that the individual had the following characteristics: married, lives in an SMSA, works in a large firm, has 10 years of market experience, and 4 years of tenure with his employer. All other variables are the mean values, and the year is 1992.
} 
utilize the data on the $R \& D$ /sales ratio. Whenever a slope is significantly different from zero, we indicate it with an "S" mark.

There are several insights from Table 6 and Figures 1-4. First, at higher rates of technological change the gap between the training incidence of the highly educated and the less educated narrows. Second, in spite of the narrowing, we still observe a positive correlation between education and training. Third, the education interactions are not monotonic and significant effects are observed for only one or two educational groups. ${ }^{23}$ In the case of production workers, workers with some high school and high school graduates train significantly more at higher rates of technological change. Since this group represents three-quarters of our production worker sample, this explains the positive relationship between training and technological change reported earlier. For non-production workers, we find that the 13-15 group trains more at higher rates of technological change, while those with more than 16 years of schooling train less at higher rates of technological change. ${ }^{24}$

These education-technological change interaction results are consistent with the hypothesis developed and tested by Bartel and Lichtenberg (1987). Bartel and Lichtenberg argue that highly-educated workers have a comparative advantage with respect to learning and implementing new technologies, and hence that the demand for these workers relative to the demand for less-educated workers is a declining function of experience with the technology. When a new technology is first introduced, there is a great deal of uncertainty about job tasks and highly educated workers are needed to help the firm through this difficult implementation stage. The general skills of the highly educated workforce serve as a substitute for company training. As experience with the new technology is gained, however,

\footnotetext{
2This could be due to the small number of cases for some education groups.

${ }^{24}$ They do, however, train more than other schooling groups, even at high rates of technological change.
} 
it is possible to train the less educated employees to perform the new tasks. Hence, since we are measuring "permanent" differences across industries in the rate of technological change, we would expect to observe a larger impact of technological change on the training incidence of less educated workers. ${ }^{25}$ In terms of the policy issue discussed in the Introduction regarding the widening earnings gap between the highly educated and the less educated, these results show that this gap is not due to a widening gap in the acquisition of post-schooling human capital. If anything, technological change has acted to reduce the gap in the stocks of human capital accumulated through formal company training by different education groups. The reasons for the widening earnings gap are more likely due to one or both of the following: skill-biased technological change which has increased the market price for the skills of the highly educated and differences in the rate of accumulating human capital through informal, on-the-job learning.

We recognize that one reason for the observed narrowing of the formal training gap between education groups could be selectivity. At higher rates of technological change, firms are less likely to employ or retain the less able employees within each education group. This bias is likely to be more pronounced for the less educated workers, resulting in an overestimate of the impact of technological change on the training of the less educated. We attempted to correct for this bias by including a set of ability test scores (not reported here), and our results on the impact of technological change were virtually unchanged. We did find, however, a positive and significant correlation between ability (holding schooling constant) and the likelihood of training, and a smaller coefficient on education.

We have interpreted our findings as indicating that the observed differences in training are due to higher rates of technological change. Alternatively, one could argue that

\footnotetext{
2SIf job training is more likely to be informal at higher levels of education, it could bias our results. Notice, however, that we do find a monotonic increase of training with the level of schooling (Appendix B).
} 
our results are due to differences in the nature of technology across industries. Perhaps industries that we rank higher on the dimension of technological change are simply industries that use more sophisticated technologies. These technologies may require more initial training in order for the worker to learn how to use them. If this hypothesis is correct, we would expect to see more training (especially formal training) when workers join the firm and virtually no impact of our "technological change" proxies on the training of more tenured workers.

In order to distinguish these two possible effects, we interact the measures of technological change with two dummies, one indicating that the worker has tenure of one year or less with the employer and the other indicating tenure of more than one year. Our assumption is that the effect of the technological change measures on longer tenured workers are more likely to reflect the response to technological change. ${ }^{25}$

Table 7 reports the estimated coefficients on the technological change variables on the likelihood of training, separated for tenure levels below and above one year. If our earlier results were due simply to the cross-sectional differences in the nature of technology, we would not expect to observe significant coefficients for workers beyond their first year of tenure. The results in Table 7 show that, although the measured effects of the technological change variables are larger for individuals with less than one year of tenure, all of the technological change proxies have positive and significant effects on longer-tenured production workers. ${ }^{27}$ Hence these results provide support for our claim that what we are indeed measuring is the effect of technological change, not the nature of technology, and ongoing technological change results in training of workers beyond their first year of tenure.

\footnotetext{
${ }^{26} \mathrm{~A}$ more accurate distinction would be based on tenure in job assignment, which we do not observe.

${ }^{27}$ As in Table 3, the coefficients on the Yale innovation measure are not significant.
} 


\section{B. Hours of Company Training}

In Table 8 we report the Tobit estimates of the effects of the various technological change measures on hours of company training received since the last survey. Complete Tobit regressions (for one specification) are shown in Appendix $C$ where it can be observed that more educated workers have more hours of training. Table 8 reports the partial derivatives and elasticities on the technological change measures and then decomposes them into the change that is due to the increase in the incidence of training and that which is due to the increase in hours of training, given positive hours. The main finding of the Tobit analysis is that the change in hours of training is due largely to the increase in participation; the ratio of the derivative due to the change in participation divided by the total derivative is approximately .85 .

One limitation of the standard Tobit model is that it does not allow for different signs on the effect of technological change on the selection into training and its effect on hours of training, given selection. In order to allow for such a possibility, we reestimated the models presented in Table 8 using a general Tobit specification, where separate coefficients are estimated for the effect of technological change on selection and its effect on hours. Our results (not reported here) reject the hypothesis that, while technological change increases the incidence of training, it reduces the number of hours per spell. We found that, in virtually all models, the effect of technological change on hours per spell was positive and insignificant. This confirms the findings of the standard Tobit model that the effects of technological change on training are incidence-, not duration-related.

\section{The Effects of Prior Training}

The results of the Tobit analysis indicate that technological change increases training at the extensive margin, i.e. the incidence of training, not hours conditional on participation, increases. In order to be more confident in this conclusion, we exploit the panel nature of 
the NLSY data. We examine whether higher rates of technological change induce firms to provide training to individuals who have already received training or to those who did not receive training in the prior period. If the latter is true, then technological change serves an important function; it acts to increase the proportion of workers who receive training. We test this hypothesis in Table 9 by interacting the various measures of technological change with two dummy variables, one indicating the individual received training in the prior year (i.e. between $t-2$ and $t-1$, since the dependent variable is training between $t-1$ and $t$ ), and the other indicating no training in the prior year. In columns (1) and (2) the sample is restricted to individuals who did not change industries between time periods $t-2$ and $t$, and in columns (3) and (4) we restrict the analysis to individuals who did not change employers between the two time periods. The results show insignificant effects of technological change for previously trained workers and significant effects for most of the technological change indicators for individuals who did not receive training in the prior year. The increase in incidence of training due to technological change occurs because different individuals are now receiving training.

\section{Summary and Implications}

The human capital investments that take place during the early years of employment have important implications for future career development. In this paper we have analyzed the impact of technological change on young workers' investments in on-the-job training. We have shown that human capital theory does not provide a clear prediction on the sign of this relationship. While higher rates of obsolescence will decrease the amount of investment, on-the-job training will increase if technological change increases the productivity of human capital, reduces the cost of training, or increases the value of time in training relative to work. The impact of technological change on the post-schooling investments of different 
education groups is also theoretically ambiguous; although more educated workers train more, we show that, in the presence of technological change, a weaker relationship between education and training may exist.

We linked data in the NLSY to six different measures of industry technological change in order to empirically resolve the ambiguous theoretical predictions. Our findings can be summarized as follows: (1) Controlling for a set of worker, job, and industry characteristics, workers in industries with higher rates of technological change are more likely to receive formal company training than those working in industries with lower rates of technological change. (2) This finding holds for all but one of the six proxies for the rate of technological change in an industry. (3) While more educated workers are more likely to receive training, the training gap between the highly educated and the less educated narrows, on average, as the rate of technological increases. (4) The observed increase in hours of training due to technological change is due to an increase in the likelihood of training, not an increase in hours of training, given participation. Technological change therefore acts to increase the extensive margin of training, increasing the pool of trainees.

Policymakers have been concerned about the likely impact of technological change on the future careers of young workers. Our results show that, while education and training are complements, at higher rates of technological change, employers compensate for workers' lower levels of education by providing more training. The post-school training gap between the more and less educated actually narrows at higher rates of technological change and the proportion of individuals receiving training increases. Previous research has shown that technological change contributes to an increase in the wage gap between less and more educated workers. Our findings show the need for further research to uncover the actual mechanisms by which technological change increases the wage gap. 


\section{Reterences}

Allen, Steven G., "Technology and the Wage Structure," mimeo., presented at NBER Summer Institute in Labor Economics, July 1992.

Barron, John M., Dan A. Black, and Mark A. Loewenstein, "Employer Size: The Implications for Search, Training, Capital Investment, Starting Wages and Wage Growth," Journal of Labor Economics 5 (January 1987): 76-89.

Bartel, Ann P., "Employee Training Programs in U.S. Businesses," in David Stern and Jozef M.M. Ritzen, editors, Market Failure in Training? New Economic Analysis and Evidence on Training of Adult Employees, Springer-Verlag, 1991.

Bartel, Ann P. and Frank R. Lichtenberg, "The Comparative Advantage of Educated Workers in Implementing New Technology," Review of Economics and Statistics 69 (February 1987): 1-11.

Bartel, Ann P., and Frank R. Lichtenberg, "The Age of Technology and Its Impact on Employee Wages," Economics of Innovation and New Technology 1 (1991): 215-231.

Bartel, Ann P. and Nachum Sicherman, "Technological Change and Retirement Decisions," Journal of Labor Economics 11 (January 1993).

Ben-Porath, Yoram. "The Production of Human Capital and the Life Cycle of Earnings," Journal of Political Economy 75 (August 1967): 352-365.

Berman, Eli, John Bound, and Zvi Griliches, "Changes in the Demand for Skilled Labor Within U.S. Manufacturing Industries: Evidence from the Annual Survey of Manufacturing," Quarterly Journal of Economics, May 1994.

Blinder Alan S., and Yoram Weiss, "Human Capital and Labor Supply: A Synthesis" Journal of Political Economy 84 (1976): 449-472.

Bound, John, and George Johnson, "Changes in the Structure of Watges During the 1980s: An Evaluation of Alternative Explanations," American Economic Review, 82

(June 1992), 371-92.

Davis, Steve, and John Haltiwanger "Gross Job Creation, Gross Job Destruction, and Employment Reallocation" The Quarterly Journal of Economics, (August 1992), 819-863.

Ghez, Gilbert, and Gary S. Becker, "The Allocation of Time and Goods over the Life Cycle". New York: Columbia University Press, 1975.

Gill, Indermit, "Technological Change, Education, and the Obsolescence of Human Capital: Some Evidence for the U.S.," manuscript, State University of New York at Buffalo. May 1990.

Griliches, Zvi, "Productivity, R\&D, and the Data Constraint," American Economic Review 84 (March 1994), $1-23$.

Griliches, Zvi and Frank Lichtenherg, "R\&D and Productivity Growth at the Industry Level: Is There Still a Relationship?" in Zvi Griliches, ed., R\&D, Patents, and Productivity,

(Cambridge: NBER. 1984).

Heckman, James, "A Life Cycle Model of Earnings, Learning, and Consumption" Journal of Political Economy 84 (August 1976): 511-44. 
Hirsch, Barry and David A. MacPherson, "Union Memhership and Coverage Files from the Current Population Surveys: Note," Industrial and Lahor Relations Review, 46, (April 1993): 574-578.

Jorgenson, Dale W., Frank M. Gollop and Barbara M. Fraumeni, Productivity and U.S. Economic Growth, (Cambridge: Harvard University Press, 1987).

Kortum, Samuel and Shaul Lach, "Patents and Productivity Growth in U.S. Manufacturing Industries" Mimeo, February, 1995.

Krueger, Alan B., "How Computers Have Changed the Wage Structure: Evidence from Microdata, 1984-1989," Quarterly Journal of Economics, (February 1993): 33-60.

Levhari, David, and Yoram Weiss, "The Effects of Risk on the Investment in Human Capital," American Economic Review 64 (December 1974): 950-63

Lichtenberg, Frank and Donald Siegel, "The Impact of R\&D Investment on Productivity: New Evidence Using Linked R\&D-LRD Data," Economic Inquiry 29 (April 1991): 203-228.

Light, Audrey and Manuelita Ureta, "Gender Differences in Wages and Job Turnover Among Continuously Employed Workers," American Economic Review 80 (May 1990): 293-297.

Lillard, Lee A. and Hong W. Tan, Training: Who Gets It and What Are Its Effects on Emplovment and Earnings? (Santa Monica: RAND Corporation Report R-3331-DOL/RC, 1986).

Lynch, Lisa M., "The Role of Off-the-Job and On-the-Job Training for the Mobility of Young Workers," American Economic Review 81 (May 1991): 151-156.

, "Private-Sector Training and the Earnings of Young Workers," American Economic Review 82 (March 1992a): 299-312.

. "Differential Effects of Post-School Training on Early Career Mobility," NBER Working Paper No. 4034, March 1992b.

McDonald, J, and Moffitt R., "The Uses of Tobit Analysis," Review of Economics and Statistics, 62, 1980, (May 1980): 318-321.

Mincer, Jacob, "Human Capital Responses to Technological Change in the Labor Market, NBER Working Paper No. 3207, December 1989.

Mincer, Jacob and Yoshio Higuchi, "Wage Structures and Labor Turnover in the United States and Japan," Journal of the Japanese and International Economies 2 (June 1988): 97-133.

National Science Foundation, Research and Development in Industry: 1990, NSF 94-304, (Arlington, Va, 1993).

Sicherman, Nachum, "The Measurement of On-the-Job Training," Journal of Economic and Social Measurement 16 (1990): 221-230.

Sicherman, Nachum, "Over-Education in the Lahor Market," Journal of Lahor Economics vol 9, no. 2, April 1991: 101-122.

Siegel, Donald, "The Impact of Technological Change on Employment and Wages: Evidence from a Panel of Long Island Manufacturers," paper presented at C.V. Starr Conference on Technologies and Skills, New York University, December 2-3, 1994. 
Tan, Hong W., "Technical Change and lts Consecutences for Training and Earnings, " manuscript, RAND Corporation, 1989.

Topel, Robert H. and Michael P. Ward, "Job Mobility and the Careers of Young Men," Quarterly Journal of Economics 107 (May 1992): 439-479.

Williams, Joseph T., "Uncertainty and the Accumulation of Human Capital Over the Life Cycle," Journal of Business 52, (1979): 521-548.

Wolpin, Kenneth, "The Determinants of Black-White Differences in Early Employment Careers: Search, Layotfs, Quits and Endogenous Wage Growth," Journal of Political Economy 100 (June 1992): 535-560. 
Table 1

Annual Incidence and Duration (Mean/Median) of Private-Sector Training, by Type of Training and Schooling Level Manufacturing Industries, Males, 1988-1992

\begin{tabular}{|c|c|c|c|c|c|c|c|c|c|c|}
\hline & \multicolumn{2}{|c|}{ All Workers } & \multicolumn{2}{|c|}{ Schooling < 12} & \multicolumn{2}{|c|}{ Schooling $=12$} & \multicolumn{2}{|c|}{ Schooling 13-15 } & \multicolumn{2}{|c|}{ Schooling 16+ } \\
\hline & * Trn & Hrs & Trn & Hrs & * Trn & Hrs & * Trn & Hrs & " Tm & Hrs \\
\hline All Training & $\begin{array}{l}.174 \\
(4041)\end{array}$ & $\begin{array}{l}142 / 40 \\
(326)\end{array}$ & $\begin{array}{l}.101 \\
(922)\end{array}$ & $\begin{array}{l}125 / 56 \\
(176)\end{array}$ & $\begin{array}{l}.157 \\
(1722)\end{array}$ & $\begin{array}{l}194 / 43 \\
(418)\end{array}$ & $\begin{array}{l}.179 \\
(609)\end{array}$ & $\begin{array}{l}112 / 41 \\
(227)\end{array}$ & $\begin{array}{l}.302 \\
(683)\end{array}$ & $\begin{array}{l}110 / 40 \\
(287)\end{array}$ \\
\hline Company & $\begin{array}{l}.133 \\
(4041)\end{array}$ & $\begin{array}{l}102 / 40 \\
(258)\end{array}$ & $\begin{array}{l}.055 \\
(922)\end{array}$ & $\begin{array}{l}81 / 44 \\
(103)\end{array}$ & $\begin{array}{l}.104 \\
(1722)\end{array}$ & $\begin{array}{l}129 / 40 \\
(320)\end{array}$ & $\begin{array}{l}.144 \\
(609)\end{array}$ & $\begin{array}{l}97 / 40 \\
(216)\end{array}$ & $\begin{array}{l}.286 \\
(682)\end{array}$ & $\begin{array}{l}92 / 36 \\
(2+7)\end{array}$ \\
\hline $\begin{array}{l}\text { Appren- } \\
\text { liceship }\end{array}$ & .011 & $\begin{array}{l}466 / 290 \\
(6.54)\end{array}$ & .011 & $\begin{array}{l}500 / 400 \\
(3 \mid 6)\end{array}$ & .015 & $\begin{array}{l}513 / 200 \\
(817)\end{array}$ & .010 & $\begin{array}{c}52 / 52 \\
\text { (2 obs.) }\end{array}$ & .001 & $\begin{array}{l}560 \\
(1 \text { ob. })\end{array}$ \\
\hline Other & .036 & $\begin{array}{l}232 / 80 \\
(4 / 4)\end{array}$ & .038 & $\begin{array}{l}100 / 4 x \\
(116)\end{array}$ & .042 & $\begin{array}{l}280 / 80 \\
(463)\end{array}$ & .034 & $\begin{array}{l}168 / 55 \\
(260)\end{array}$ & .019 & $\begin{array}{l}356 / 10 \\
(658)\end{array}$ \\
\hline
\end{tabular}

Large Finns

\begin{tabular}{|c|c|c|c|c|c|c|c|c|c|c|}
\hline All Training & $\begin{array}{l}.233 \\
(1837)\end{array}$ & $\begin{array}{l}135 / 40 \\
(325)\end{array}$ & $\begin{array}{l}100 \\
(279)\end{array}$ & $\begin{array}{l}131 / 56 \\
(203)\end{array}$ & $\begin{array}{l}.186 \\
(793)\end{array}$ & $\begin{array}{l}175 / 40 \\
(404)\end{array}$ & $\begin{array}{l}.234 \\
(303)\end{array}$ & $\begin{array}{l}103 / 40 \\
(222)\end{array}$ & $\begin{array}{c}392 \\
(+28)\end{array}$ & $\begin{array}{l}126 / 40 \\
(317)\end{array}$ \\
\hline Company & .199 & $\begin{array}{l}101 / 40 \\
(245)\end{array}$ & .072 & $\begin{array}{l}80 / 52 \\
(92)\end{array}$ & .146 & $\begin{array}{l}111 / 32 \\
(255)\end{array}$ & .195 & $\begin{array}{l}91 / 40 \\
(205)\end{array}$ & .367 & $\begin{array}{l}105 / 40 \\
(274)\end{array}$ \\
\hline $\begin{array}{l}\text { Appren- } \\
\text { ticeship }\end{array}$ & .011 & $\begin{array}{l}695 / 402 \\
(859)\end{array}$ & .0017 & $\begin{array}{l}600 / 600) \\
(2 \text {, olss.) }\end{array}$ & .016 & $\begin{array}{l}864 / 402 \\
(1062)\end{array}$ & .016 & $\begin{array}{l}3.2 / 3.2 \\
(1 \text { obs. })\end{array}$ & .002 & $\begin{array}{l}560 \\
(1, b .)\end{array}$ \\
\hline Other & .031 & $\begin{array}{l}223 / 60 \\
(426)\end{array}$ & .029 & $\begin{array}{l}103 / 48 \\
(104)\end{array}$ & .030 & $\begin{array}{l}253 / 70 \\
(4+1)\end{array}$ & .040 & $\begin{array}{l}142 / 40 \\
(281)\end{array}$ & .030 & $\begin{array}{l}356 / 100 \\
(658)\end{array}$ \\
\hline \multicolumn{11}{|l|}{ Sinall Finus } \\
\hline All Training & $\begin{array}{l}.124 \\
(2200)\end{array}$ & $\begin{array}{l}153 / 40 \\
(330)\end{array}$ & $\begin{array}{l}.101 \\
(640)\end{array}$ & $\begin{array}{l}120 / 52 \\
(155)\end{array}$ & $\begin{array}{l}.132 \\
(978)\end{array}$ & $\begin{array}{l}219 / 52 \\
(437)\end{array}$ & $\begin{array}{l}.124 \\
(306)\end{array}$ & $\begin{array}{l}132 / 53 \\
(241)\end{array}$ & $\begin{array}{l}.150 \\
(254)\end{array}$ & $\begin{array}{l}45 / 24 \\
(x 2)\end{array}$ \\
\hline Company & .077 & $\begin{array}{l}106 / 36 \\
(288)\end{array}$ & .048 & $\begin{array}{l}82 / 44 \\
(116)\end{array}$ & .069 & $\begin{array}{l}16 \mid / 40 \\
(4 \mid 3)\end{array}$ & .095 & $\begin{array}{l}109 / 40 \\
(244)\end{array}$ & .150 & $\begin{array}{l}45 / 24 \\
(82)\end{array}$ \\
\hline $\begin{array}{l}\text { Appren- } \\
\text { liceship }\end{array}$ & .010 & $\begin{array}{l}238 / 200 \\
(222)\end{array}$ & .012 & $\begin{array}{l}433 / 400 \\
(3 \text { obs. })\end{array}$ & .013 & $\begin{array}{l}163 / 47 \\
(6 \text { obs. })\end{array}$ & .003 & $\begin{array}{l}100 \\
(1 \text { ob. })\end{array}$ & 0.0 & NONE \\
\hline Other & .044 & $\begin{array}{l}240 / 96 \\
(408)\end{array}$ & .042 & $\begin{array}{l}99 / 68 \\
(125)\end{array}$ & .052 & $\begin{array}{l}293 / 80 \\
(479)\end{array}$ & .029 & $\begin{array}{l}240 / 192 \\
(4 \text { obs.) }\end{array}$ & 0.0 & NONE \\
\hline
\end{tabular}

- Numbers in parentheses are observations (for incidence, " $T\left(\mathrm{Tm}^{*}\right.$ ) and standard deviation (for hours, "Hrs"). Mean and median hours are calculated for positive hours only. 
Table 2

Indices for Industry Rates of Technological Change

\section{Investment in computers as a share of total investment}

\section{CPS Code Industry}

Ordnance
Electronic computing equipment

Radio, T.V. and communication equipment

Office and accounting machines

Scientific and controlling instruments

Leather products, except footwear

Aircraft and parts

Newspaper publishing and printing

Not specified machinery

Railroad locomotives

Not specified electrical machinery, equipment, and supplies

Printing, publishing, and allied industries, except newspapers

Not specitied protessional equipment

Machinery, except electrical

Not specified manufacturing industries

Footwear, except rubber

Miscellaneous manutacturing industries

Metalworking machinery

Electrical machinery, equipment and supplies

Ship and boat building and repairing

Glass and glass products

Drugs and medicines

Photographic equipment and supplies

Construction and material handling machines

Optical and health services supplies

Tobacco inanutactures

Engines and turbines

Tanned, curried, and finished leather

Fabricated structural metal products

Paints, varnishes, and related products

Miscellaneous fabricated textile products

Apparel and accessories

Mobile dwellings and campers

Watches, clocks, and clockwork-operated devices

Miscellaneous fabricated metal products

Cutlery, hand tools, and other hardivare

Furniture and fixture

Pottery and related products

Miscellaneous petroleum and coal products

Floor covering:s, except hard surface

Screw machine products

Cycles and miscellaneous transportation equipment

Household appliances

Miscellaneous nonmetallic mineral and stone products

Grain-mill products

Primary aluminum industries
Share of Investment 
Not specified metal industries $\quad .038$

Soaps and cosmetics $\quad .037$

Farm machinery and equipment

Rubber products

Dairy products

.037

Dyeing and finishing textiles, except wool and knit goods $\quad .036$

Canning and preserving fruits, vegetables and sea foods

.033

Structural clay products

.031

Paperboard containers and boxes

.030

Miscellaneous plastic products

.028

Not specified chemicals and allied products

.027

Knitting mills $\quad 027$

Miscellaneous food preparation and kindred products $\quad .026$

Sawmills, planing mills and mill work $\quad .025$

Miscellaneous chemicals $\quad .025$

Miscellaneous paper and pulp products $\quad .024$

Beveraye industries $\quad .024$

Agricultural chemicals $\quad .023$

Industrial chemicals $\quad .023$

Not specified food industries $\quad .023$

Metal stamping $\quad .023$

Bakery products $\quad .020$

Motor vehicles and motor vehicle $\quad .020$

Miscellaneous textile mill products $\quad .020$

Plastics, synthetics and resins, except tibers $\quad .018$

Blast furnaces, steel works, rolling and finishing mills $\quad .018$

Petroleum retining $\quad .016$

Pulp, paper, and paperboard mills $\quad .015$

Other primary iron and steel industries $\quad .014$

$\begin{array}{ll}\text { Confectionery and related products } & .014\end{array}$

Meat products $\quad .014$

Cement, concrete, gypsum and plaster products $\quad .012$

Yam, thread, and fabric mills $\quad .012$

Miscellaneous wood products $\quad .007$

$\begin{array}{ll}\text { Synthetic tihers } & .002\end{array}$

Logging $\quad .000$

\section{Growth of Investment in Computers, 1982-1987}

1 Office \& accounting machines (357 exc. 3573)

2 Radio, T.V., \& communication equipment $(365,366) \quad .11225$

3 Railroad locomotives \& equipment (374) 10713

4 Leather products, exc. footwear $(312,315-317,319) \quad 10209$

5 Aircraft \& parts (372) $\quad .07961$

6 Footwear, except rubber $(313,314) \quad 07311$

7 Glass \& glass products (321-323)

8 Machinery, exc. electrical, n.e.c. $(355,356,358,359) \quad .06815$

9 Not specified electrical machinery, equipment, \& supplies 06443

10 Scientific \& controlling instruments $(381,382) \quad 06419$

11 Ship \& boat building \& repairing (373)

12 Not specified manufacturing industries $\quad .06336$

13 Tobacco manufactures (21) 05946 
14 Miscellaneous manufacturing industries (39)

.05812

Drugs \& medicines (283)

05720

Tanned, curried, \& finished leather (311)

Not specified machinery

05343

Construction \& material handling machines (353) $\quad .05125$

Printing, publishing, \& allied industries, exc newspapers $\quad .05041$

Metalworking machinery (354)

.05032

Paints, varnishes, \& related products $(285)$

04993

Optical \& health services supplies $(383,384,385)$

.04231

Miscellaneous petroleum \& coal products $(295,299)$

.04118

Electrical machine, equipment, \& supplies, n.e.c.

.03981

Not specified professional equipment

.03977

Fabricated structural metal products (344)

.03909

Engines \& turbines (351)

.03888

Mobile dwellings \& campers (3791)

.03883

Miscellaneous fabricated textile products (239)

03849

Pottery \& related products (326)

03731

Grain-mill products (204, 0713)

03410

Cutlery, hand tools, \& other handwate (342)

Floor coverings, exc, hard surface (227)

Apparel \& accessories (231-238) $\quad .02968$

Structural clay products (325)

Miscellaneous fabricated metal products

Watches, clocks, \& clock-work-operated devices (387)

Primary aluminum industries

02723

Dairy products (202)

.02591

02507

.02330

.02325

.02112

.02096

02023

.02016

.01973

01886

.01857

.01660

.01648

.01613

.01607

.01588

.01560

.01432

.01426

.01390

.01226

.01223

.01116

.01104

.01040

.00790

.00706

.00683

.00607

67 Miscellaneous paper \& pulp products (264) 
Metal stamping (346)

.00605

Miscellaneous textile mill products (229) 00596

Newspaper publishing \& printing (271) $\quad 00516$

Knitting mills (225)

.00336

$\begin{array}{ll}\text { Other primary iron \& steel industries } & .00314\end{array}$

Bakery products (205)

.00283

Yarn, thread, \& fabric mills $(221-224,228) \quad 00223$

Meat products (201)

.00181

.00096

$\begin{array}{ll}\text { Cement, concrete, gypsum, \& plaster products }(324,327) & .00031 \\ \text { Ordinance (19) } & -.00029\end{array}$

Ordinance (19)

$-.00077$

Miscellaneous wood products $(244,249)$

$-.00199$

Logging (241)

$-.00600$

Synthetic fibers (2823.2824)

82 Dyeing \& finishing textiles, exc. wool \& knit goods

$-.01178$

Blast furnaces, steel works, rolling \& finishing mills

$-.01180$

\section{Jorgenson's TFP}

1 Non-electrical machinery $\quad 025861$

2 Petroleum refining $\quad .020192$

3 Electrical machinery $\quad .019077$

4 Apparel \& other textile $\quad .016959$

5 Chemicals \& allied $\quad .016570$

6 Textile mill products $\quad .015416$

7 Miscellaneous Manufacturing $\quad .014244$

8 Rubber \& plastic $\quad .012264$

9 Other transportation equipment $\quad .011727$

10 Furniture and fixtures $\quad .010903$

11 Instruments $\quad .009004$

12 Paper \& allied products $\quad .008890$

13 Lumber and wood products $\quad .008340$

14 Fabricated metal $\quad .006900$

15 Leather $\quad .006687$

16 Stone, clay and glass .004865

17 Primary metals $\quad .002812$

18 Food \& kindred products $\quad .002277$

19 Tobacco manufactures $\quad-.001611$

20 Motor vehicles -.002123

21 Printing \& publishing $\quad-.005576$

\section{TFP, NBER Dataset, Means over 1977-87}

1 Electronic computing equipment $\quad .17557$

2 Not specified machinery $\quad .04299$

3 Synthetic fibers $\quad .03719$

4 Ordinance $\quad .03564$

5 Miscellaneous textile mill products $\quad .03456$ 
6 Grain-mill products $\quad .02947$

7 Radio, T.V., \& communication equipment $\quad .02815$

8 Petroleum refining $\quad .02704$

9 Screw machine products $\quad .02677$

10 Not specified chemicals \& allied products $\quad .02449$

11 Confectionery \& related products $\quad .02369$

12 Miscellaneous plastic products $\quad .02338$

13 Knitting mills $\quad .02100$

14 Optical \& health services supplies $\quad .01840$

15 Not specified electrical machinery, equipment, \& supplies $\quad .01782$

16 Floor coverings, exc. hard surface $\quad .01733$

17 Agricultural chemicals $\quad .01731$

18 Rubber products $\quad .01726$

19 Miscellaneous fabricated textile products $\quad .01714$

20 Household appliances $\quad .01540$

21 Beverage industries $\quad .01492$

22 Industrial chemicals $\quad .01460$

23 Yarn, thread, \& fabric mills $\quad .01448$

24 Sawmills, planing mills, a nd mill work $\quad .01423$

25 Paints, varnishes, \& related products $\quad .01346$

26 Pulp, paper, \& paperboard mills $\quad .01342$

27 Apparel \& accessories $\quad .01313$

28 Plastics, synthetics \& resins, exc. fibers $\quad .01288$

29 Structural clay products $\quad .01273$

30 Logging $\quad .01255$

31 Cement, concrete, gypsum, \& plaster products $\quad .01193$

32 Electrical machine, equipment, \& supplies, n.e.c. $\quad .01168$

33 Miscellaneous wood products $\quad .01124$

34 Miscellaneous chemicals $\quad .01021$

35 Dairy products $\quad .01015$

36 Bakery products $\quad .00957$

37 Other primary conferrous industries $\quad .00953$

38 Furniture \& fixtures $\quad .00882$

39 Fabricated structural metal products $\quad .00835$

40 Dyeing \& finishing textiles, exc. wool \& knit goods $\quad .00792$

41 Printing, publishing, \& allied industries, except newspapers $\quad .00780$

42 Blast furnaces, steel works, rolling \& finishing mills $\quad .00728$

43 Not specified professional equipment $\quad .00710$

44 Office \& accounting machines $\quad .00655$

45 Not specified metal industries $\quad .00630$

46 Photographic equipment \& supplies $\quad .00609$

47 Miscellaneous paper \& pulp products $\quad .00516$

48 Other primary iron \& steel industries $\quad .00489$

49 Miscellaneous fabricated metal products $\quad .00459$

50 Canning \& preserving fruits, vegetables, \& sea foods $\quad .00423$

51 Footwear, except rubber $\quad .00415$

52 Miscellaneous petroleum \& coal products $\quad .003577$ 
53 Mobile dwellings \& campers

.003540

54 Meat products

.003251

55 Pottery \& related products

.003249

56 Leather products, exc. footwear

.003090

57 Glass \& glass products

.003054

58 Cutlery, hand tools, \& other handware

.001652

59 Paperboard containers \& boxes

.001114

60 Not specitied food industries

.001097

61 Not specified manufacturing industries

.000785

62 Miscellaneous manufacturing industries

.000784

63 Scientific \& controlling instruments

.000705

64 Watches, clocks, \& clock-work-operated devices

.000630

65 Miscellaneous food preparation \& kindred products

$-.000138$

66 Miscellaneous nonmetallic mineral \& stone products

$-.000595$

67 Drugs \& medicines

$-.000653$

68 Motor vehicles \& motor vehicle equipment

$-.001119$

69 Primary aluminum industries

$-.001193$

70 Cycles \& miscellaneous transportation equipment

$-.001255$

71 Metal stamping

$-.001359$

72 Aircraft \& parts

$-.002037$

73 Machinery, exc. electrical, n.e.c.

$-.002936$

74 Ship \& boat building \& repairing

$-.003132$

75 Soaps \& cosmetics

$-.003367$

76 Newspaper publishing \& printing

$-.004294$

77 Metalworking machinery

$-.006743$

78 Engines \& turbines

$-.009734$

79 Farm machinery \& equipment

$-.017799$

80 Railroad locomotives \& equipment

$-.020352$

81 Construction \& material handling machines

$-.020607$

82 Tanned, curried, \& finished leather

$-.029667$

83 Tobacco manufactures

$-.038326$

V. Company and other (except Federal) R\&D funds as a percent of net sales in R\&Dperforming manufacturing companies, means over 1984-1990

\section{Industry}

Office, computing, and accounting machines

Drugs and medicines

Scientific and mechanical measuring instruments

Electronic components

Instruments

Communication equipment

Industrial chemicals

Motor vehicles and motor vehicles equipment

Radio and TV receiving equipment

\section{Mean R\&D}

12.5714

8.7429

8.5000

8.2143

7.3286

5.2571

4.2714

3.4143

3.3857 
Other chemicals

3.3429

Other machinery, except electrical

2.8714

Other transportation equipment

2.3143

Stone, clay, and glass products

2.2714

Other electrical equipment

2.2286

Rubber products

1.7286

Nonferrous metals and products $\quad 1.3143$

Fabricated metal products $\quad 1.2000$

Other Manufacturing Industries $\quad 1.0857$

$\begin{array}{ll}\text { Stone, clay, and glass products } & 1.0857\end{array}$

$\begin{array}{ll}\text { Professional and scientific instruments } & 1.0857\end{array}$

Petroleum refining and extraction $\quad 0.9286$

Paper and allied products $\quad 0.7286$

$\begin{array}{ll}\text { Lumber, wood products, and furniture } & 0.6857\end{array}$

$\begin{array}{ll}\text { Ferrous metals and products } & 0.6000\end{array}$

Food, kindred, and tobacco products $\quad 0.5286$

Textiles and apparel

0.4429

VI. The Rate of Introduction of New Production Processes (Yale Dataset).

\section{Industry}

1 Tobacco manufacturers

2 Photographic equipment and supplies

3 Guided missiles, space vehicles, and parts

4 Electronic computing equipment

5 Cutlery, handtools, and other hardware

6 Radio, T.V., and communication equipment

7 Logging

8 Aircraft and parts

9 Meat products

10 Not specified electrical machinery, equipment, \& supplies

11 Sawmills, planing mills, and millwork

12 Pottery and related products

13 Electrical machinery, equipment, and supplies, n.e.c.

14 Farm machinery and equipment

15 Metalworking machinery

16 Not specified machinery

17 Miscellaneous paper and pulp products

18 Glass and glass products

19 Iron and steel foundries

20 Not specified professional equipment

21 Drugs

22 Optical and health services supplies

23 Sugar and confectionery products

24 Motor vehicles and motor vehicle equipment

25 Paperboard containers and boxes

$\begin{array}{ll}\text { Rate } & \text { Observations } \\ 6.00000 & 1.0000 \\ 6.00000 & 2.0000 \\ 5.75000 & 4.0000 \\ 5.57143 & 21.000 \\ 5.17529 & 1.8247 \\ 4.81008 & 16.113 \\ 4.75000 & 4.0000 \\ 4.68725 & 11.189 \\ 4.66667 & 3.0000 \\ 4.61272 & 11.716 \\ 4.55237 & 3.5257 \\ 4.50000 & 2.0000 \\ 4.40495 & 6.9572 \\ 4.40000 & 5.0000 \\ 4.38660 & 4.8268 \\ 4.33960 & 9.4429 \\ 4.33333 & 6.0000 \\ 4.33333 & 3.0000 \\ 4.28571 & 7.0000 \\ 4.27565 & 10.531 \\ 4.23529 & 17.000 \\ 4.18992 & 7.5140 \\ 4.17556 & 1.0000 \\ 4.06938 & 12.612 \\ 4.00000 & 6.0000 \\ & \end{array}$


Ordnance

$4.00000 \quad 1.0000$

Household appliances

$4.00000 \quad 1.0000$

Miscellaneous manufacturing industries

$4.00000 \quad 1.0000$

Miscellaneous plastics products

3.96429

28.000

30

Petroleum refining

$3.90000 \quad 10.000$

Construction and material handling machines

$3.85086 \quad 5.3631$

32

Plastics, synthetics, and resins

3.83760

13.555

33 Tires and inner tubes

3.83333

6.0000

Machinery, exc. electrical, n.e.c.

$3.78388 \quad 5.0378$

Scientific and controlling instruments

$3.74319 \quad 16.156$

Other primary metal industries

$3.73167 \quad 1.7146$

37 Not specified manufacturing industries

$3.69854 \quad 2.8088$

38 Industrial and miscellaneous chemicals

3.68717

16.962

Screw machine products

3.66667

3.0000

40

Miscellaneous fabricated metal products

3.56351

5.0856

41

Engines and turbines

$3.54392 \quad 5.2094$

42 Soaps and cosmetics

$3.53891 \quad 11.853$

Not specified metal industries

$3.50947 \quad 4.6228$

44

Toys, amusement, and sporting goods

3.50000

4.0000

Furniture and fixtures

3.47868

1.0000

46 Pulp, paper, and paperboard mills

$3.46755 \quad 12.866$

47 Blast furnaces, steelworks, rolling and finishing mills

3.40000

10.000

48

Metal forgings and stampings

$3.40000 \quad 5.0000$

49

Railroad locomotives and equipment

3.33333

3.0000

50 Miscellaneous nonmetallic mineral and stone products

3.21132

2.4397

5

Not specified food industries

3.15564

3.0482

3.14821

4.9926

3.00000

1.0000

53

Printing, publishing, allied industries, exc. newspapers

3.00000

8.0000

54

Paints, varnishes, and related products

2.97157

4.8388

56 Fabricated structural metal products

2.72981

2.2974

57

Grain mill products

2.67527

3.3025

58

Ship and boat building and repairing

2.66667

3.0000

59 Miscellaneous food preparations and kindred products

2.42857

7.0000

60

Dairy products

2.41501

3.4900

61 Primary aluminum industries

$2.34286 \quad 4.4286$

62

Bakery products

2.00000

2.0000

63

Structural clay products

2.00000

1.0000

64 Office and accounting machines

2.00000

1.0000

65 Cement, concrete, gypsum, and plaster products

1.79645

2.0859

VII. Patents Used by Industry (total of 1980-83 divided by 1970-79)

Office and computing machines $\quad .4366$

Communication and electronics $\quad .4049$

Petroleum refinaries \& extractions .3962 
Other electrical equipment

Prof. and scientific instruments

Other manufacturing

Drugs

Stone, clay and glass products

Transportation equipment

Industrial chemicals

Fabricated metals products

Other nonelectrical machinery

Primary metals products

Rubber and plastics products

Other chemicals

Paper products

Aircraft and missiles

Food and kindred products

Lumber and furniture

Textile and apparel
.3779

.3581

.3572

.3528

.3478

.3418

.3418

.3414

.3386

.3301

.3299

.3280

.3275

.3199

.3176

.3166

.2998 
Table 3

The Effects of Technological Change on the Likelihood of Company Training in the Manufacturing Sector

\begin{tabular}{|c|c|c|c|c|c|c|}
\hline \multirow[b]{2}{*}{ I. Jorgenson TFP } & \multicolumn{2}{|l|}{ All } & \multicolumn{2}{|c|}{ Production } & \multicolumn{2}{|c|}{ Non-Production } \\
\hline & $\begin{array}{l}25.26 \\
(.002)\end{array}$ & .021 & $\begin{array}{l}32.95 \\
(.004)\end{array}$ & .018 & $\begin{array}{l}9.56 \\
(.457)\end{array}$ & .013 \\
\hline $\begin{array}{l}\text { II. Share of Investment } \\
\text { in computers }\end{array}$ & $\begin{array}{l}2.11 \\
(.09)\end{array}$ & .010 & $\begin{array}{l}3.90 \\
(.058)\end{array}$ & .012 & $\begin{array}{l}-.02 \\
(.99)\end{array}$ & -.0002 \\
\hline $\begin{array}{l}\text { III. Growth of Investment } \\
\text { in computers }\end{array}$ & $\begin{array}{l}3.089 \\
(.19)\end{array}$ & .008 & $\begin{array}{l}4.854 \\
(.19)\end{array}$ & .008 & $\begin{array}{l}.962 \\
(.76)\end{array}$ & .001 \\
\hline IV. NBER TFP & $\begin{array}{l}2.36 \\
(.10)\end{array}$ & .006 & $\begin{array}{l}5.99 \\
(.022)\end{array}$ & .01 & $\begin{array}{l}.002 \\
(.999)\end{array}$ & .00001 \\
\hline V. Yale Innovation Rate & $\begin{array}{l}.129 \\
(.10)\end{array}$ & .011 & $\begin{array}{l}.028 \\
(.81)\end{array}$ & .002 & $\begin{array}{l}.141 \\
(.20)\end{array}$ & .02 \\
\hline VI. R\&D to Sales ratio & $\begin{array}{l}.0805 \\
(.001)\end{array}$ & .021 & $\begin{array}{l}.1622 \\
(.0001)\end{array}$ & .026 & $\begin{array}{l}.0289 \\
(.378)\end{array}$ & .012 \\
\hline VII. Use of Patents & $\begin{array}{l}6.13 \\
(.005)\end{array}$ & .016 & $\begin{array}{l}10.85 \\
(.0025)\end{array}$ & .018 & $\begin{array}{l}1.267 \\
(.661)\end{array}$ & .005 \\
\hline
\end{tabular}

${ }^{\mathrm{a}}$ In parentheses, below the logit coefficients, are estimated probability that the coefficient is not different from zero. To the right of each estimated coefficient is the derivative $(\mathrm{dP} / \mathrm{dX})$, multiplied by standard deviation of measure of technoligical change. The derivative is calculated as $\beta \hat{P}(1-\hat{P})$, where $\hat{P}$ is the mean incidence of training in the sample.

The values for the standard deviations are: .0086 for jorgenson's TFP, .05 for Investment in computers, .026 for growth in investment in computers, .027 for the NBER TFP, .86 for the Yale measure, 2.57 for the R\&D to sales ratio, and .027 for use of patents. The mean rates of training for the subsamples in the regressions are .111 for all workers in manufacturing, .067 for production workers, and .196 for non-production workers. 
Table 4

The Effects of Technological Change on the Likelihood of All Types of Training \& NonCompany Training in the Manufacturing Sector

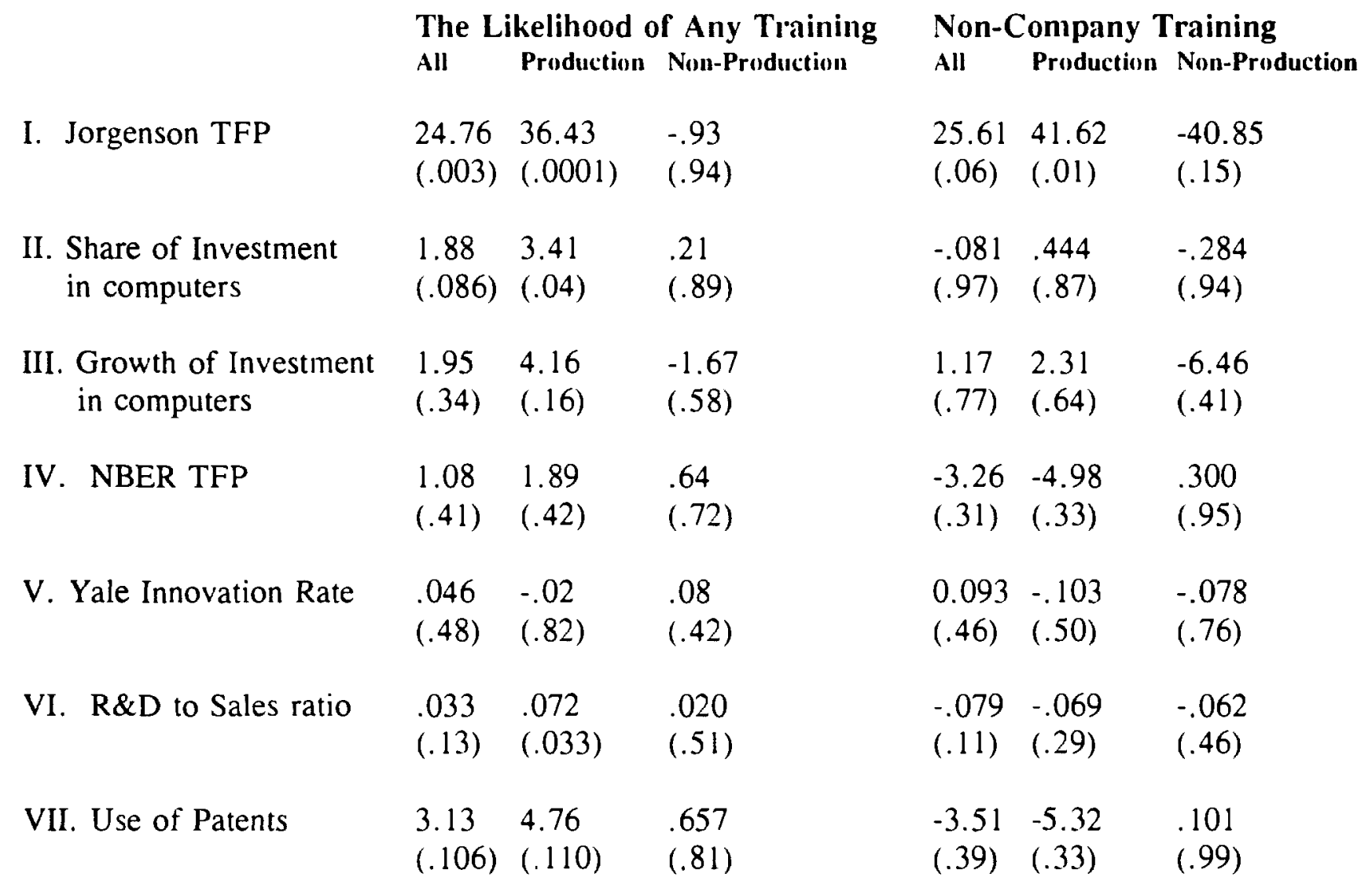

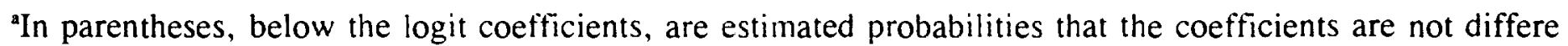
from zero. 
Table 5

Interaction Effects of Technological Change and Education on the Likelihood of Company Training in the Manufacturing Sector

\begin{tabular}{|c|c|c|c|}
\hline & All & Production & Non-Production \\
\hline I. Jorgenson TFP & $\begin{array}{l}58.68 \\
(.10)\end{array}$ & $\begin{array}{l}-3.92 \\
(.95)\end{array}$ & $\begin{array}{l}122.8 \\
(.05)\end{array}$ \\
\hline Years of Education & $\begin{array}{l}.26 \\
(.0001)\end{array}$ & $\begin{array}{l}.09 \\
(.26)\end{array}$ & $\begin{array}{l}.31 \\
(.0001)\end{array}$ \\
\hline Jorg. * Educ & $\begin{array}{l}-2.54 \\
(.33)\end{array}$ & $\begin{array}{l}3.10 \\
(.56)\end{array}$ & $\begin{array}{l}-8.10 \\
(.05)\end{array}$ \\
\hline II. Inv. in Computers & $\begin{array}{l}25.76 \\
(.0001)\end{array}$ & $\begin{array}{l}49.61 \\
(.0001)\end{array}$ & $\begin{array}{l}24.76 \\
(.007)\end{array}$ \\
\hline Years of Education & $\begin{array}{l}.347 \\
(.0001)\end{array}$ & $\begin{array}{l}.393 \\
(.0001)\end{array}$ & $\begin{array}{l}.332 \\
(.0001)\end{array}$ \\
\hline Computers*Educ & $\begin{array}{l}-1.62 \\
(.0001)\end{array}$ & $\begin{array}{l}-3.74 \\
(.0004)\end{array}$ & $\begin{array}{l}-1.58 \\
(.0078)\end{array}$ \\
\hline III. Growth of Computers & $\begin{array}{l}37.91 \\
(.0038)\end{array}$ & $\begin{array}{l}94.226 \\
(.0003)\end{array}$ & $\begin{array}{l}29.125 \\
(.159)\end{array}$ \\
\hline Years of Education & $\begin{array}{l}.304 \\
(.0001)\end{array}$ & $\begin{array}{c}.3635 \\
(.0001)\end{array}$ & $\begin{array}{l}.258 \\
(.0001)\end{array}$ \\
\hline Computers*Educ & $\begin{array}{l}-2.447 \\
(.0093)\end{array}$ & $\begin{array}{l}-7.283 \\
(.0006)\end{array}$ & $\begin{array}{l}-1.776 \\
(.1937)\end{array}$ \\
\hline IV. NBER TFP & $\begin{array}{l}24.45 \\
(.003)\end{array}$ & $\begin{array}{l}20.78 \\
(.26)\end{array}$ & $\begin{array}{l}28.39 \\
(.023)\end{array}$ \\
\hline Years of Education & $\begin{array}{l}.25 \\
(.0001)\end{array}$ & $\begin{array}{l}.14 \\
(.009)\end{array}$ & $\begin{array}{l}.24 \\
(.0001)\end{array}$ \\
\hline NBER * Educ & $\begin{array}{l}-1.52 \\
(.006)\end{array}$ & $\begin{array}{l}-1.25 \\
(.408)\end{array}$ & $\begin{array}{l}-1.86 \\
(.021)\end{array}$ \\
\hline V. Yale Innovation Rate & $\begin{array}{l}.526 \\
(.20)\end{array}$ & $\begin{array}{l}-.472 \\
(.54)\end{array}$ & $\begin{array}{l}2.247 \\
(.0014)\end{array}$ \\
\hline Years of Education & $\begin{array}{l}.321 \\
(.007)\end{array}$ & $\begin{array}{l}-.059 \\
(.808)\end{array}$ & $\begin{array}{l}.761 \\
(.0001)\end{array}$ \\
\hline Yale*Education & $\begin{array}{l}-.030 \\
(.31)\end{array}$ & $\begin{array}{l}.038 \\
(.54)\end{array}$ & $\begin{array}{l}-.140 \\
(.0025)\end{array}$ \\
\hline VI. R\&D to Sales Ratio & $\begin{array}{l}.436 \\
(.0001)\end{array}$ & $\begin{array}{l}.340 \\
(.088)\end{array}$ & $\begin{array}{l}.508 \\
(.002)\end{array}$ \\
\hline Years of Education & $\begin{array}{l}.291 \\
(.0001)\end{array}$ & $\begin{array}{r}.147 \\
(.032)\end{array}$ & $\begin{array}{l}.303 \\
(.0001)\end{array}$ \\
\hline$R \& D *$ Education & $\begin{array}{l}-.025 \\
(.0004)\end{array}$ & $\begin{array}{c}-.015 \\
(.341)\end{array}$ & $\begin{array}{l}.031 \\
(.002)\end{array}$ \\
\hline VII. Use of Patents & $\begin{array}{l}37.56 \\
(.0002)\end{array}$ & $\begin{array}{l}41.68 \\
(.047)\end{array}$ & $\begin{array}{l}36.09 \\
(.022)\end{array}$ \\
\hline Years of Education & $\begin{array}{l}.987 \\
(.0001)\end{array}$ & $\begin{array}{l}1.029 \\
(.086)\end{array}$ & $\begin{array}{l}1.00 \\
(.007)\end{array}$ \\
\hline Patents*Education & $\begin{array}{l}-2.197 \\
(.002)\end{array}$ & $\begin{array}{l}-2.59 \\
(.129)\end{array}$ & $\begin{array}{l}-2.28 \\
(.027)\end{array}$ \\
\hline
\end{tabular}


Table 6

The effects of Technological Change on the Likelihood of Company Training

by Level of Education

\begin{tabular}{|c|c|c|c|c|c|c|c|}
\hline & $\begin{array}{l}\text { Jorgenson's } \\
\text { TFP }\end{array}$ & $\begin{array}{l}\text { Share of invest. } \\
\text { in Computers }\end{array}$ & $\begin{array}{l}\text { Growth of comp. } \\
\text { investment }\end{array}$ & $\begin{array}{l}\text { NISER's } \\
\text { THP' }\end{array}$ & $\begin{array}{l}\text { Yale's rate of } \\
\text { innovation }\end{array}$ & $\begin{array}{l}\text { R\&D to Salex } \\
\text { Ratio }\end{array}$ & $\begin{array}{l}\text { Patents } \\
\text { Used }\end{array}$ \\
\hline \multicolumn{8}{|c|}{ 1. All Workers in Manufacturing } \\
\hline \multirow[t]{2}{*}{$1-8$ years } & 51.7 & 13.35 & 31.3 & -58.9 & -.39 & .26 & -3.08 \\
\hline & $(.35)$ & $(.26)$ & $(.10)$ & $(.22)$ & $(.46)$ & $(.40)$ & $(.85)$ \\
\hline \multirow[t]{2}{*}{$9-11$ years } & -13.62 & 4.35 & 6.67 & 6.34 & -.16 & .058 & .052 \\
\hline & $(.47)$ & $(.25)$ & $(.42)$ & $(.20)$ & $(.45)$ & $(.47)$ & $(.99)$ \\
\hline \multirow[t]{2}{*}{12 years } & 25.18 & 4.22 & 4.18 & 5.69 & .07 & .121 & -2.71 \\
\hline & $(.017)$ & $(.020)$ & $(.22)$ & $(.04)$ & $(.42)$ & $(.0005)$ & $(.013)$ \\
\hline \multirow[t]{2}{*}{ 13-15 ycars } & 14.13 & 4.73 & 7.92 & 4.99 & .20 & .136 & 8.76 \\
\hline & $(.39)$ & $(.034)$ & $(.11)$ & $(.078)$ & $(.22)$ & $(.0006)$ & $(.031)$ \\
\hline \multirow[t]{2}{*}{16 years } & 26.25 & -3.61 & -8.7 & -.54 & -.10 & 0013 & -5.09 \\
\hline & $(.051)$ & $(.05)$ & $(.059)$ & $(.80)$ & $(.44)$ & $(.97)$ & $(.12)$ \\
\hline \multirow[t]{2}{*}{$17+$ ycurs } & -15.69 & -.07 & 2.26 & -1.56 & .013 & .005 & .323 \\
\hline & $(.40)$ & $(.98)$ & $(.72)$ & $(.64)$ & $(.95)$ & $(.91)$ & $(.95)$ \\
\hline \multicolumn{8}{|c|}{ II. Production Workers } \\
\hline \multirow[t]{2}{*}{$1-8$ years } & 95.46 & 15.8 & 36.1 & -52.5 & -.12 & $36 ?$ & 2.15 \\
\hline & $(.14)$ & $(.22)$ & $(.097)$ & $(31)$ & $(.85)$ & $(.24)$ & $(.91)$ \\
\hline \multirow[t]{2}{*}{$9-11$ years } & -5.06 & 7.4 & 11.0 & 8.9 & -.24 & .139 & 3.12 \\
\hline & $(.80)$ & $(.077)$ & $(.22)$ & $(.096)$ & $(31)$ & $(.096)$ & $(.68)$ \\
\hline \multirow[t]{2}{*}{12 ye:ars } & 36.5 & 48 & 6.83 & 5.87 & -.07 & 170 & -.131 \\
\hline & $(.009)$ & $(.051)$ & $(.12)$ & $(.11)$ & (.57) & $(.0002)$ & $(.96)$ \\
\hline \multirow[t]{2}{*}{ 13-15 years } & 35.4 & .68 & -.47 & 2.94 & .05 & 142 & -51 \\
\hline & $(.17)$ & $(.86)$ & $(.96)$ & $(.57)$ & $(.84)$ & $(.027)$ & $(.94)$ \\
\hline \multirow[t]{2}{*}{16 years } & 44.9 & -100 & -100 & -2.47 & -.62 & -.17 & .31 .76 \\
\hline & $(.29)$ & $(.15)$ & $(.02)$ & $(89)$ & $(.27)$ & $(.45)$ & $(.08)$ \\
\hline \multirow[t]{2}{*}{$17+$ years } & -5.11 & -18.5 & -30 & .854 & -.57 & .051 & -5.19 \\
\hline & $(.94)$ & $(.40)$ & $(.43)$ & $(.95)$ & $(.58)$ & $(.74)$ & $(.84)$ \\
\hline \multicolumn{8}{|c|}{ III. Non I'roduction Workers } \\
\hline \multirow[t]{2}{*}{$1-8$ years } & -183 & -19.2 & -12.7 & -240 & -1.17 & -4.65 & .89 .9 \\
\hline & $(.34)$ & $(.62)$ & $(.80)$ & $(.44)$ & $(.34)$ & $(.47)$ & $(.38)$ \\
\hline \multirow[t]{2}{*}{$9-11$ years } & -9.23 & -21.7 & -27.9 & -11.3 & .73 & .45 & -28.03 \\
\hline & $(.87)$ & $(.23)$ & $(.38)$ & $(.70)$ & $(.28)$ & $(.38)$ & $(.31)$ \\
\hline \multirow[t]{2}{*}{12 years } & 21.15 & 2.62 & 1.36 & 3.72 & -.04 & .071 & -2.48 \\
\hline & $(.23)$ & $(.35)$ & $(.81)$ & $(.44)$ & $(.71)$ & $(.19)$ & $(.06)$ \\
\hline \multirow[t]{2}{*}{$13-15$ years } & -16.7 & 6.59 & 11.4 & 5.45 & .27 & .135 & 12.47 \\
\hline & $(.46)$ & $(.031)$ & $(.09)$ & $(.12)$ & $(.27)$ & $(.009)$ & $(.019)$ \\
\hline \multirow[t]{2}{*}{16 years } & 8.38 & -3.22 & -5.1 & -1.27 & -.07 & -.020 & -4.42 \\
\hline & $(.61)$ & $(.123)$ & $(.29)$ & $(.58)$ & (.63) & $(.59)$ & $(.22)$ \\
\hline \multirow[t]{2}{*}{$17+$ years } & -35.4 & -.41 & 2.63 & -3.06 & -.02 & -.019 & -.338 \\
\hline & $(.097)$ & $(.88)$ & $(.68)$ & $(.39)$ & $(.91)$ & $(.70)$ & $(.95)$ \\
\hline
\end{tabular}


Table 7

First Year and Beyond: Is the Effect of Technological Change Different in First Year of Tenure?

Production

\section{Jorgenson TFP}

Low Tenure

High Tenure

II. Inv. in Computers

Low Tenure

High Tenure

III. Growth of Computers

Low Tenure

High Tenure

IV. NBER TFP

Low Tenure

High Tenure

V. Yale rate of Innovation

Low Tenure

High Tenure

VI. R\&D to Sales Rate

Low Tenure

High Tenure

VII. Use of Patents

Low Tenure

High Tenure
39.48

$(.027)$

31.69

$(.007)$
Non-Production

.726

(.967)

11.572

(.377)

$-2.38$

(.330)

.578

(.737)

$-.444$

(.933)

1.28

(.696)

$-4.74$

(.213)

.962

(.617)

.077

(.59)

.158

(.157)

$-.016$

(.744)

.038

(.252)

.860

(.77)

1.40

(.63) 
Table 8

The Effects of Technological Change on Hours of Company Training

Tobit "Decomposition" Analysis

Using Different Measures of Technological Change; Males Workers; Manufacturing

(standard errors in parentheses)

Measure of Tec. Change

\& Group of Workers

Tobit Marginal Effect

$\partial y / \partial X$

Der.

Elast.

$\begin{array}{ll}206 & .234 \\ (88) & (.101) \\ 258 & .384 \\ (98) & (.146) \\ -74.85 & .060 \\ (229) & (.184)\end{array}$

\section{NBER TFP}

All workers

Production

Non-Production
Due to Change Panticipation

$E\left(y^{*}\right)\left[\partial F(z) / \partial X_{j}\right]$

Der. Elast.

$\begin{array}{ll}177 & .201 \\ (76) & (.086) \\ 226 & .336 \\ (86) & (.128) \\ -61 & -.050 \\ (189) & (.152)\end{array}$

12.71

.019

(14.43) (.021)

$33.37 \quad .050$

(22.18) (.033)

$-7.44 \quad-.011$

(27.55) (.039)
Due to increased hours

$F(z)\left[\partial E y * / \partial X_{j}\right]$
Der.

$\begin{array}{ll}29 & .033 \\ (12.5) & (.14) \\ 31 & .047 \\ (12) & (.18) \\ -13 & -.010 \\ (40) & (.032)\end{array}$

$2.09 \quad .003$

(2.38) (.003)

$4.73 \quad .007$

(3.17) (.005)

$-1.57 \quad-.002$

(5.82) (.008)

Share of Investment in Computers

\begin{tabular}{lllll}
\hline All workers & 18.44 & .119 & 15.84 & .103 \\
& $(14.08)$ & $(.092)$ & $(12.09)$ & $(.078)$ \\
Production & 14.02 & .107 & 12.28 & .093 \\
& $(18.69)$ & $(.142)$ & $(16.37)$ & $(.125)$ \\
Non-Production & 17.10 & .093 & 14.11 & .077 \\
& $(30.24)$ & $(.165)$ & $(24.96)$ & $(.136)$
\end{tabular}

$\begin{array}{ll}2.60 & .017 \\ (1.99) & (.012) \\ 1.74 & .013 \\ (2.32) & (.017) \\ 2.98 & .016 \\ (5.28) & (.029)\end{array}$

Growth of Investment in Computers

\begin{tabular}{lll}
\hline All workers & 42.91 & .127 \\
& $(25.75)$ & $(.076)$ \\
Production & 21.23 & .078 \\
& $(32.59)$ & $(.12)$ \\
Non-Production & 74.82 & .170
\end{tabular}

$\begin{array}{ll}36.87 & .109 \\ (22.12) & (.066) \\ 18.60 & .068 \\ (28.54) & (.105) \\ 61.79 & .141 \\ (45.32) & (.10)\end{array}$

$6.04 \quad 018$

(3.63) (.01)

$2.63 \quad 010$

(4.04) (.015)

$13.03 \quad .029$

(54.90) (.125)

(45.32)

(.10)

(9.59)

(.02)

Yale Data

\begin{tabular}{lllll}
\hline All workers & .467 & .156 & .400 & .133 \\
& $(.974)$ & $(.324)$ & $(.833)$ & $(.277)$ \\
Production & -.32 & -.149 & -.287 & -.130 \\
& $(1.11)$ & $(.502)$ & $(.967)$ & $(.439)$ \\
Non-Production & .918 & .206 & .752 & .169 \\
& $(2.36)$ & $(.529)$ & $(1.93)$ & $(.433)$
\end{tabular}

$\begin{array}{ll}.067 & .022 \\ (.140) & (.047) \\ -.041 & -.019 \\ (.139) & (.063) \\ .165 & .037 \\ (.425) & (.095)\end{array}$


Table 8 (cont.)

The Effects of Technological Change on Hours of Company Training Tobit "Decomposition" Analysis

Using Different Measures of Technological Change; Males Workers; Manufacturing

Measure of Tec. Change

\& Group of Workers

Tobit Marginal Effect

$\partial y / \partial X_{j}$

Der.

Elast.

$\begin{array}{ll}.699 & .161 \\ (.285) & (.066) \\ 1.034 & .259 \\ (.38) & (.095) \\ .477 & .101 \\ (.602) & (.128)\end{array}$

Use of Patents

All workers

Production

Non-Production

R\&D/Sales Ratio

All workers

Production

Non-Production
Due to Change Participation

$E\left(y^{*}\right)\left[\partial F(z) / \partial X_{j}\right]$

Der. Elast.

$\begin{array}{ll}47.88 & 1.64 \\ (24.95) & (.86) \\ 63.43 & 2.92 \\ (33.09) & (1.53) \\ 16.90 & .39 \\ (52.86) & (1.23)\end{array}$

$\begin{array}{ll}.600 & .138 \\ (.245) & (.565) \\ .906 & .227 \\ (.333) & (.083) \\ .394 & .083 \\ (.497) & (.105)\end{array}$

$41.11 \quad 1.41$

(21.42) (.73)

$55.58 \quad 2.56$

(28.97) (1.33)

$13.94 \quad .32$

(43.63) (1.01)
Due to increased hours

$F(z)\left[\partial E y * / \partial X_{j}\right]$
Der.
Elast.

$\begin{array}{ll}.098 & .022 \\ (.041) & (.009) \\ .127 & .032 \\ (.048) & (.012) \\ .017 & .083 \\ (.022) & (.105)\end{array}$

$6.75 \quad .23$

(3.54) (.12)

$\begin{array}{ll}7.85 & .36\end{array}$

(4.14) (.19)

$2.95 \quad .07$

(9.23) (.21) 
Table 9

Past_Training, Technological Change, and Current Training: Interacting Technological Change with Past Training Dummies"

Didn't change industry (2 digit) Didn't change employer

Production Non-Production Production Non-Production

\section{Jorgenson TFP}

$\begin{array}{lllll}\text { Past Training } & 2.42 & -6.61 & -19.2 & -10.6 \\ & (.94) & (.79) & (.49) & (.66) \\ \text { No Past Training } & 31.55 & -.53 & 26.5 & -8.7 \\ \text { II. Inv. in Computers } & (.08) & (.98) & (.12) & (.64) \\ \text { Past Training } & & & & \\ & 6.12 & -3.02 & .679 & -2.67 \\ \text { No Past Training } & (.21) & (.37) & (.87) & (.42) \\ & 5.57 & .431 & 4.73 & 3.61 \\ \text { III. Growth of Computers } & (.09) & (.88) & (.138) & (.15) \\ \text { Past Training } & 3.13 & -8.28 & & \\ & (.75) & (.29) & (.12 & -8.42 \\ \text { No Past Training } & 1.05 & 1.63 & 3.40 & (.30) \\ & (.87) & (.76) & (.57) & (.068) \\ \text { IV. NBER TFP } & & & & \\ \text { Past Training } & 8.38 & -.81 & -1.72 & -1.40 \\ & (.24) & (.83) & (.75) & (.71) \\ \text { No Past Training } & 9.60 & -1.78 & 6.54 & -.58 \\ & (.023) & (.57) & (.12) & (.84) \\ \text { V. Yale rate of Innovation } & & & & \\ \text { Past Training } & -.06 & .026 & -.28 & .074 \\ & (.85) & (.91) & (.33) & (.75) \\ \text { No Past Training } & .21 & .190 & .056 & .182 \\ & (.27) & (.29) & (.75) & (.26) \\ \text { VI. R\&D to Sales Rate } & & & & \\ \text { Past Training } & .151 & -.026 & .048 & -.024 \\ \text { No Past Training } & (.096) & (.67) & (.52) & (.68) \\ & .206 & -.002 & .179 & .028 \\ & (.0006) & (.97) & (.003) & (.54)\end{array}$

VII. Use of Patents

$\begin{array}{lllll}\text { Past Training } & 11.33 & -2.43 & 2.17 & -6.47 \\ \text { No Past Training } & (.23) & (.67) & (.76) & (.25) \\ & 14.35 & 4.45 & 12.26 & 4.48 \\ & (.019) & (.36) & (.03) & (.30)\end{array}$

- The dummies are: "Past training" $=1$ if the person received company training between $t-2$ and $t-1$ (the dependent variable is training between $t-1$ and $t$ ). "No Past Training" $=1$ if the person did not train between $\mathrm{t}-2$ and $\mathrm{t}-1$. In the first two columns the sample is limited to workers who did not change industry since $\mathrm{t}-2$. In the last two columns the sample is limited to workers who did not change employer since t-2. 


\section{Appendix A}

Data

\section{General}

The data are from 1979-1992 National Longitudinal Surveys of Labor Market Experience of youth ag 14-21 in 1979 (NLSY). Additional data are obtained from the NLSY work history file. The NLSY work history file contains primarily employment related spell data constructed from the main NLSY file. Both files are available in cd-rom format. Many questions are asked with regards to the time since the last survey. For the first survey (1979), the questions, in most cases, are with regards to the time period since January $1,1978$.

In addition to the NLSY, we use information from variety of sources. These are industry measures o technological change and other industry level variables. They are described in the text.

\section{The Sample}

The number of men interviewed in 1979 is 6403. Not all individuals are interviewed each year. The first observation for an individual (to be included in our sample) is the first survey in which the main activity reported for the week prior to the survey is working (1), with a job, but not working (2), or looking for a job (3). Following that, an individual is included in the sample as long as he is interviewed (even if leaving the labor market). Other restrictions apply only for specific analyses. The panel is unbalanced, and the number of observations per individual varies.

\section{CPS Job}

For each respondent, employment information on up to a maximum of 5 jobs is recorded in each survey year. One of these jobs is designated as a CPS job and it is the most recent/current job at the time of interview. Typically it is also the main job. Each job is identified by a number ( 1 to 5 ) and job \#1 in most cases is also the CPS job. For only this so called CPS job there are a host of additional employer/employee related questions that are asked in the NLSY surveys. Our analysis is restricted to CP jobs.

\section{The Work History File}

We use the work history file to construct the tenure, separation and reason for separation variables. (a) Tracing jobs and Tenure with Employer: The tenure variable is already constructed in the work history file. The major difficulty is tracing CPS jobs over the interview years. A variable called PRE allows matching of employers between consecutive interview years. For each job in a particular surve year it gives the job number that was assigned to that job in the previous year (assuming of course th the current job existed in the previous year). Our programming strategy was to pick CPS jobs in whi the respondents are actually employed at the time of interview, and to trace these jobs to the next survey year via the PREV variable in the succeeding survey year. There are, however, a few cases where we cannot trace the current CPS job in the succeeding interview year with PREV. The current tenure value is the total number of weeks worked up to the interview date. A shortcoming of PREV is that it allows for matching employers between consecutive interview years only. If, therefore, a respondent worked for a particular employer say in 1980 but not in 1981 and started working for the same employer in survey year 1982 then there is no way of knowing the total years of tenure with th employer since employer numbers are followed only in contiguous interviews. This may not be a problem for turnover analysis since re-employment with the same employer after an absence of that length (i.e., a period longer than that between two successive interview years) maybe considered a ne job.

\section{Weeks between surveys}


The number of weeks between surveys ranges between 26 and 552 weeks. The large numbers are the results of individuals not being surveyed for several years. In all our analyses we included (when it made sense) the variable WKSSINCE (weeks since last survey). The variable was excluded if it made no difference.

\section{Training:}

A variety of formal training questions were asked in all survey years, except 1987. Individuals were asked to report up to two government programs in which they were enrolled since the previous interview, and up to four vocational/technical programs. Until 1986 the maximum was two programs, and in $1988 \mathrm{i}$ was increased to four.

Up until 1986, only if the program lasted more than 4 weeks, further questions were asked, in particular the type of program and the dates it started and ended. Starting in 1988 these questions were asked about all programs, regardless of length. The four weeks condition up to 1986 is a major shortcoming of the data set. Any analysis that focus on a specific type of training (e.g. company training) has to be limited to post 1986. The following example illustrates the problem: The percentage of workers in our sample that reported enrollment in company training is $4.7 \%$ over the period 1976-1990. Limiting the sample to $1988-1990$, the rate increases to $11 \%$.

In certain years $(80-86,89-90)$ a distinction was made between programs in which the individual was enrolled at the time of the previous interview, and programs that started after the previous interview. ${ }^{28}$ When such a distinction is made, up to two programs at the time of last interview can be reported. A person was asked about training that took place at the time of last interview, only if the interviewer had a record indicating so. Therefore, fur 1980-86, such a record did not exist if training took less than a mont

For all programs the starting and ending month and year are reported. Also reported are the average number of hours per week spent in training.

In our programming we number all programs in the following order: the four vocational/technical programs are numbered 1-4, the two programs at time of last interview are numbered 5-6, and the government programs are numbered 7-8.

Type of Training: Up to 1986, the following categories are reported:

$1=$ Business College,

$2=$ Nurses Program,

$3=$ apprenticeship,

$4=$ vocational-technical Institution,

$5=$ Barber Beauty,

$6=$ Flight School,

$7=$ correspondence,

$8=$ company $/$ military,

$9=$ other.

We aggregate them into company training (8), apprenticeship (3), and "other" $(1,2,4,5,6,7,9)$. Starting in 1988, the breakdown is more detailed:

1-7 are unchanged.

$8=\quad$ A formal company training run by employer or military training (excluding basic training).

$9=$ Seminars or training programs at work run by someone other than employer,

$10=$ Seminars or training programs outside of work,

$11=$ vocational rehabilitation center,

$12=$ other.

We now aggregate $8-10$ as company training, and $11-12$ as "other". to us.

${ }^{28}$ This distinction is not obvious and could be a major source of error. We thank Lisa Lynch for pointing it 
Below are additional descriptions of some of the variables used:

Any Tech/Voc Training Dummy: Whether the worker received any technical or vocational training since (or at the time of) last interview.

Any Training Dummy (TANYD): Like the above, but also includes government training .

Company Training Dummy (TCOMD): If any of the training programs was $\# 8$ up to 85 , or $\# 8$, $\# 9$, or \#10 after 86. Notice that only after 86 the type of program was asked of all workers who reported trainin Prior to 88 , only for those who spent more than 4 weeks on training the program type question was asked (see above for more discussion of this problem).

Length of Training: Starting in 1988, in addition to asking when (Inonth and year) did different training program start and end, individuals were also asked "altogether, for how many weeks did you attend this training?". The question was not asked of government training. If the answer was 0 (less than a week), w re-coded it to half a week.

For each of the eight programs, individuals were asked for the average hours per week spent training. Multiplying the hours per week in each program with the weeks in each program, we get the total hours in each program.

Imputing training data for 1987: In 1987 no training questions were asked. We utilize the answers to th 1988 survey to construct training information for the 1987 survey. We do so by using information on the starting and ending dates of training programs. If reporting in 88 that still in training (end month $=0$ and endyr $=0$ or 1 ) we set the end date to the interview date. For some individuals the answer for the beginni date indicates "still in training". This is an error. 
Appendix $\mathrm{B}$

The Likelihood of Company Training

Estimated Logit Results

Male Workers in Manufacturing

\section{Variahle}

Intercept

If Married

If Non-White

1-8 years of schooling

9-11

13-15

16

$17+$

Lives in SMSA

Experience

Experience ${ }^{2}$

Tenure

Tenure ${ }^{2}$

Union Member

Large Firm

Durables

Industry unemployment

Industry Union Coverage

Industry jobs Creation

Industry jobs Destruction

Industry R\&D/Sales Ratio

1988

1989

1990

1991

1992
All Workers Coefficient

$-4.8890$

(0.0001)

0.2304

$(0.0564)$

$-0.2447$

(0.0913)

$-0.6689$

(0.1194)

$-0.4227$

$(0.0335)$

0.0807

(0.6259)

0.7376

(0.0001)

1.2125

$(0.0001)$

0.0350

(0.7971)

0.1660

(0.1436)

$-0.00762$

$(0.1820)$

0.0332

$(0.5406)$

$-0.00257$

$(0.5800)$

$-0.1168$

$(0.4472)$

0.8422

$(0.0001)$

$-0.1183$

$(0.4475)$

$-0.1188$

(0.0188)

0.00164

(0.7859)

$-0.0751$

$(0.3733)$

0.0965

$(0.1575)$

0.0805

(0.0010)

1.3174

(0.0001)

1.4009

(0.0001)

1.6302

(0.0001)

1.6084

(0.0001)

1.6272

(0.0001)
Production Workers Non Production

Derivative Coefficient Derivative Coefficient Derivative

$-3.6493$

$-0.2291$

$-5.9714$

$(0.0001)$

$0.023 \quad 0.2986$

$(0.1041)$

$-0.024$

$-0.2201$

$(0.2617)$

$-0.066$

$-0.2832$

$(0.5536)$

$-0.042 \quad 0.0103$

$(0.9634)$

0.008

0.1088

$(0.6557)$

$0.073 \quad 0.7315$

(0.0809)

0. 120

0.8223

(0.2075)

0.003

$-0.00371$

(0.9843)

0.016

0.0513

$(0.7477)$

$-0.001$

0.003

$-0.00396$

(0.6242)

0.0671

(0.3989)

$-0.000$

$-0.00351$

$(0.5877)$

$-0.012$

0.2006

(0.2892)

0.083

0.7805

$(0.0001)$

$-0.012$

$-0.0710$

(0.7678)

$-0.012$

$-0.0695$

(0.3382)

0.000

0.00374

(0.6451)

$-0.007$

$-0.1598$

(0.1886)

0.010

$-0.00841$

$(0.9308)$

0.008

0.1622

(0.0001)

0.130

1.3857

(0.0018)

0.138

1.4792

(0.0008)

0.161

1.8657

(0.0001)

0.159

1.9472

(0.0001)

0.161

1.9540

(0.0001)
0.0187

$-0.0138$

0.1440

$(0.3842)$

$-0.2487 \quad-0.0392$

$(0.2674)$

$\begin{array}{lll}-0.0178 & -1.3910 & -0.2191\end{array}$

0.0006

$(0.1870)$

$-1.6773$

$(0.0020)$

0.0068

$-0.3944$

(0.1013)

0.0459

0.1695

(0.4137)

0.0516

0.6579

(0.0097)

$-0.0002$

$-0.1554$

$(0.4579)$

0.0032

0.3109

$(0.0586)$

$-0.0002$

$-0.0133$

$(0.1025)$

0.0042

0.0190

(0.8052)

$\begin{array}{ll}-0.0002 & -0.00430\end{array}$

$(0.5333)$

0.0126

$-0.4278$

(0.1757)

0.0490

0.8311

$(0.0001)$

$-0.0045$

$-0.0331$

$(0.8738)$

$-0.0044$

$-0.1696$

$(0.0227)$

0.0002

0.0025 I

$(0.7892)$

$-0.0100$

0.0143

$(0.9072)$

$-0.0005$

0.1956

$(0.0540)$

0.0102

0.0289

(0.3782)

0.0870

1.3308

(0.0002)

0.0928

1.3953

(0.0001)

0.1171

1.5483

$(0.0001)$

0.1222

1.4076

(0.0002)

0. 1226

1.4738

(0.0003)
$-0.9406$

0.0227

$-0.2642$

0.0267

0.1036

$-0.0245$

0.0490

$-0.0021$

0.0030

$-0.0007$

$-0.0674$

0.1309

$-0.0052$

$-0.0267$

0.0004

0.0023

0.0308

0.0045

0.2096

0.2198

0.2439

0.2217

0.2321
$-0.0621$ 


\section{Appendix C}

The Effects of Technological Change on Hours of Company Training Tohit Estimation Results

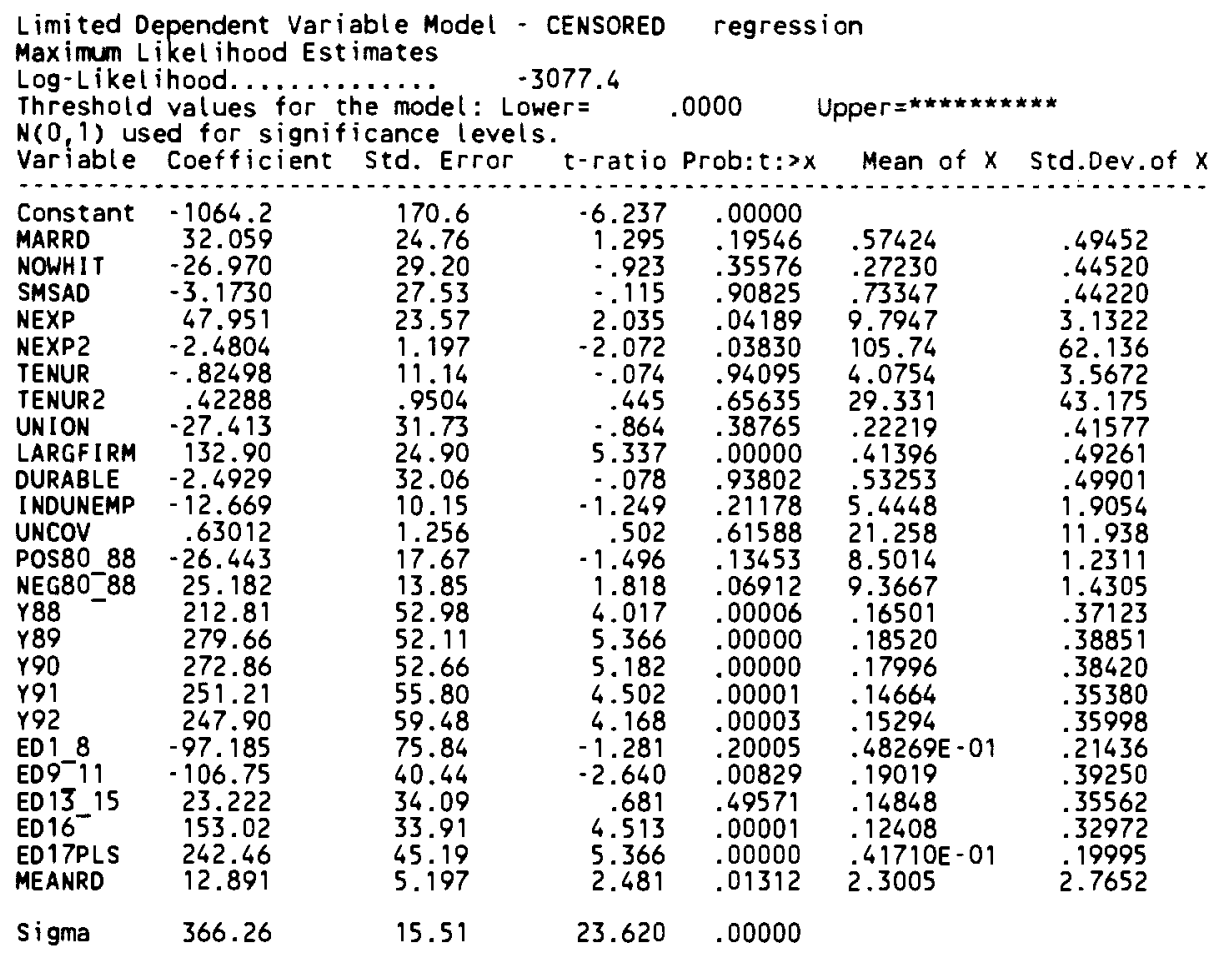


Appendix D

The Tobit Model and the McDonald \& Moffitt Decomposition

Consider the following relationship:

$$
\begin{array}{rlrl}
y_{i} & =X_{i} \beta+u_{i} & & \text { if } X_{i} \beta+u_{i}>0 \\
& =0 & \text { if } X_{i} \beta+u_{i} \leq 0
\end{array}
$$

where $y_{i}$ is the dependent variable, $X_{i}$ is a vector of independent variables, $\beta$ is a vector of unknown coefficients, and $u_{i}$ is an independently distributed error term assumed to be normal with zero mean and constant variance $\sigma^{2}$. Therefore, the assumption is that there is an underlying, stochastic index equal to $\left(X_{i} \beta+u_{i}\right)$ which is observed only when it is positive, and hence is an unobserved, latent variable. The expected value of $\mathrm{y}$ in the model is

$$
E y=X \beta F(z)+\sigma f(z)
$$

where $z=X \beta / \sigma, f(z)$ is the unit normal density, and $F(z)$ is the cumulative normal distribution function. The expected value of $y$ for observations above the limit, denoted by $y^{*}$, is $X \beta$ plus the expected value of the truncated normal error term

$$
E y^{*}=E(y \mid y>0)=E(y \mid u>-X \beta)=X \beta+\sigma \frac{f(z)}{F(z)}
$$

Consequently, the basic relationship between the expected value of all observations $(E y)$, the expected value conditional upon being above the limit $\left(E y^{*}\right)$, and the probability of being above the limit $(F(z))$, is:

$$
E y=F(z) E y^{*}
$$

The decomposition suggested by McDonald and Moffitt is obtained by considering the effect of a change in the $\mathrm{j}$ variable of $\mathrm{X}$ on $\mathrm{y}$ :

$$
\frac{\partial E y}{\partial X_{j}}=F(z)\left(\frac{\partial E y^{*}}{\partial X_{j}}\right)+E y^{*}\left(\frac{\partial F(z)}{\partial X_{j}}\right)
$$

Therefore, the total change in y can be decomposed into two parts: The change in y of those above the limit, weighted by the probability of being above the limit, and the change in the probability of being above the limit, weighted by the expected value of $y$ if above.

Each of the above terms can be evaluated at some value of $\mathrm{X} \beta$. The value of $E y^{*}$ can be calculated from equation (3). The two partial derivatives that we focus on are:

$$
\begin{aligned}
\frac{\partial F(z)}{\partial X_{j}}= & \frac{f(z) \beta_{j}}{\sigma} \quad \text { and } \\
\frac{\partial E y^{*}}{\partial X_{j}}= & \beta_{j}+\left(\frac{\sigma}{F(z)}\right) \frac{\partial f(z)}{\partial X_{j}}-\left(\sigma \frac{f(z)}{F(z)^{2}}\right) \frac{\partial F(z)}{\partial X_{j}} \\
& =\beta_{j}\left[1-z \frac{f(z)}{F(z)}-\frac{f(z)^{2}}{F(z)^{2}}\right]
\end{aligned}
$$


$C 2 P$

\section{The Likelihood of Company Training}

Using Investment in computers

Production workers. Interacting with Schooling Dummies

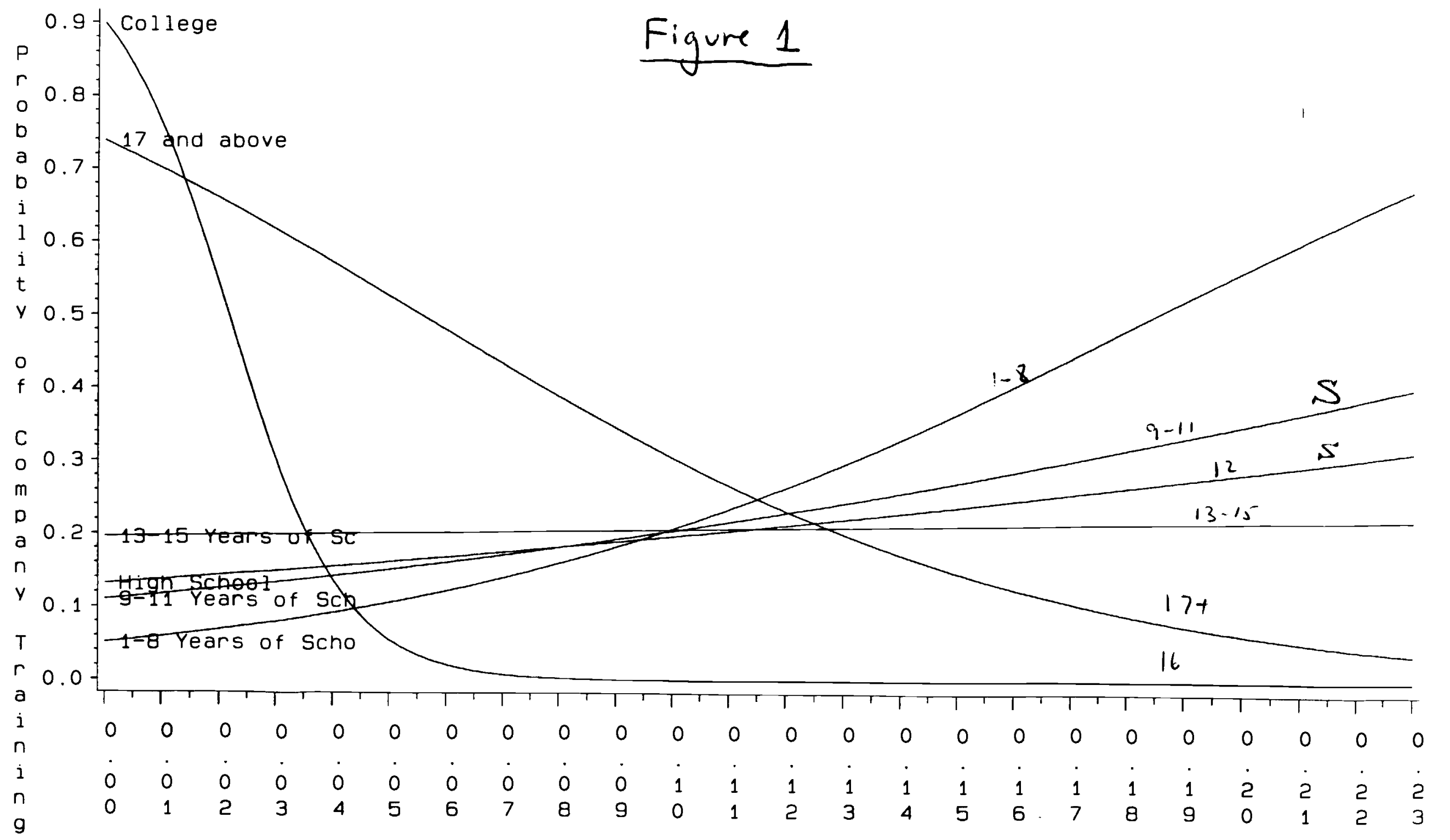




\section{The Likelihood of Company Training}

Non Production workers, Interacting with Schooling Dummies

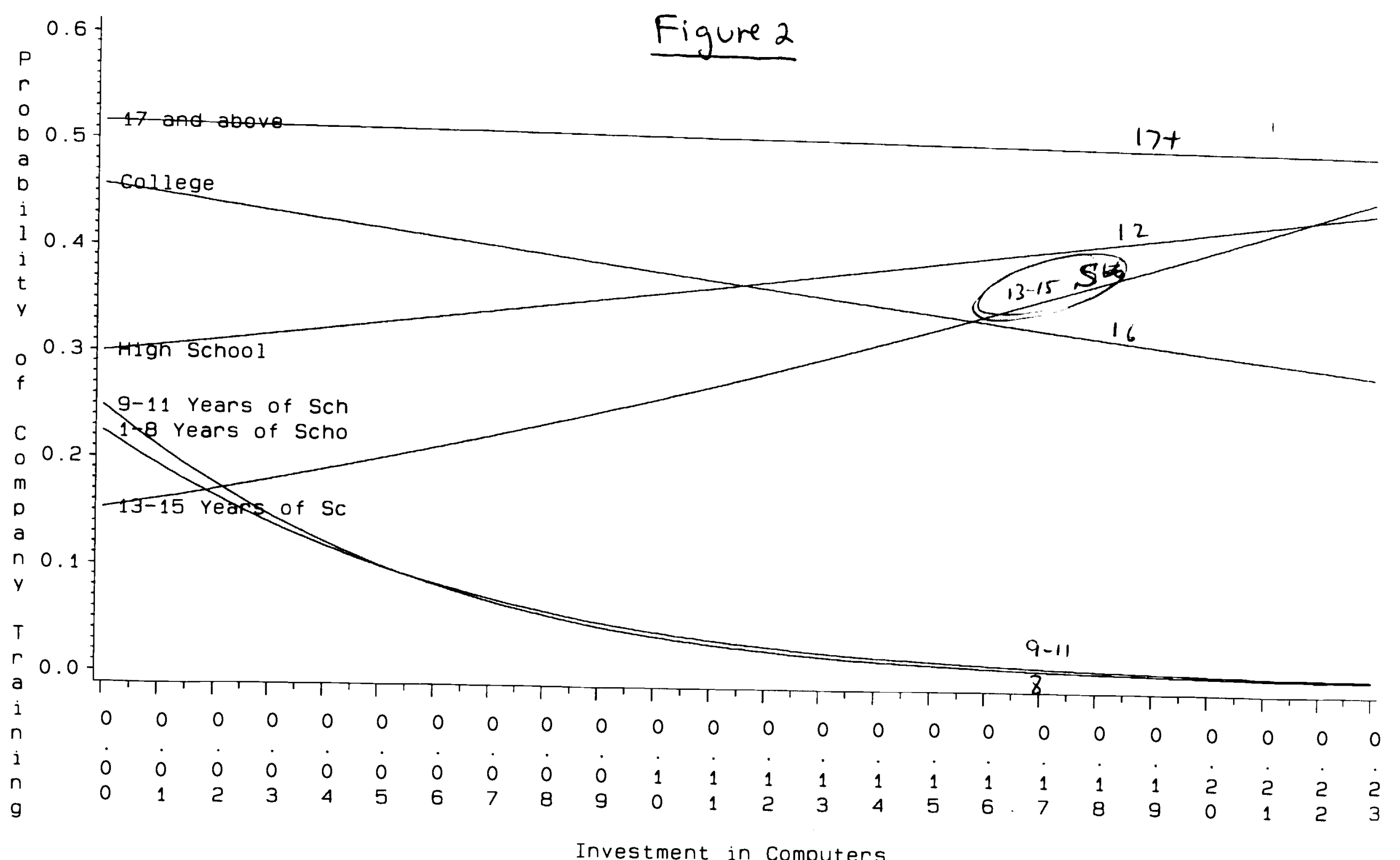

Investment in Computers 


\section{The Likelihood of Company Training}

Production workers, Using Schooling Dummies

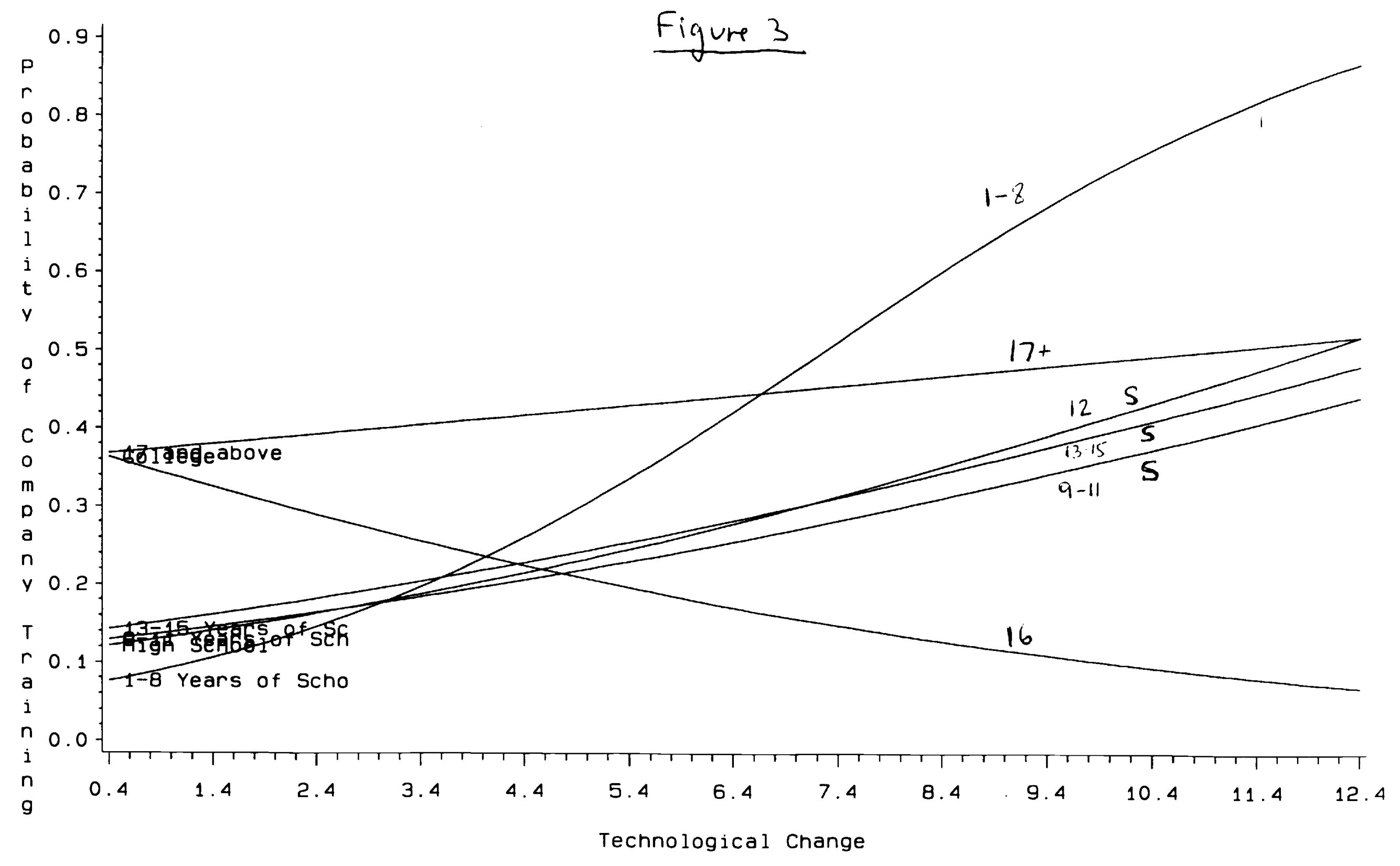




\section{The Likelihood of Company Training \\ Non Production workersing RaD to Sales}

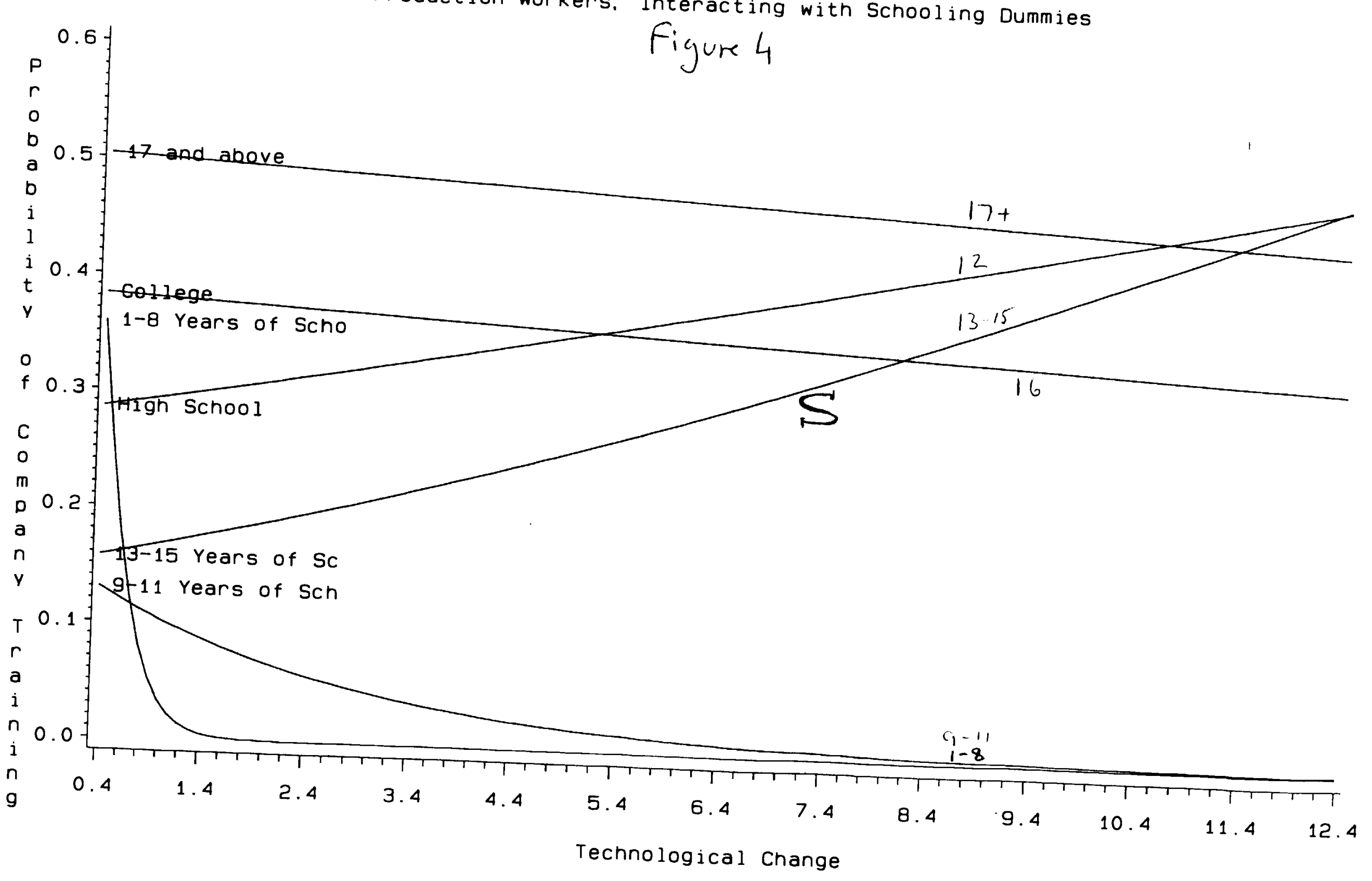

